\title{
A novel strain of Stenotrophomonas acidaminiphila produces super-active alkaline protease during cassava effluent fermentation: process optimization, kinetic modeling and scale-up
}

\author{
Atim Asitok \\ University of Calabar \\ Maurice George Ekpenyong (D maurygg2002@yahoo.com ) \\ University of Calabar, Nigeria https://orcid.org/0000-0001-9601-5546 \\ Iquo Takon
}

University of Calabar

Sylvester Antai

University of Calabar

Nkpa Ogarekpe

Cross River State University of Technology: Cross River University of Technology

Richard Antigha

Cross River University of Technology

Philomena Edet

University of Calabar

Agnes Antai

University of Calabar

Joseph Essien

University of Uyo

\section{Research Article}

Keywords: Alkaline protease activity, Cassava processing effluent bioconversion, Stenotrophomonas acidaminiphila, Response surface optimization, Kinetic modeling, Sustainable environmental pollution abatement

Posted Date: August 17th, 2021

DOI: https://doi.org/10.21203/rs.3.rs-793406/v2

License: (c) (i) This work is licensed under a Creative Commons Attribution 4.0 International License. Read Full License 



\title{
A novel strain of Stenotrophomonas acidaminiphila produces super-active alkaline protease during cassava effluent fermentation: process optimization, kinetic modeling and scale-up
}

\author{
Atim Asitok ${ }^{1,2}$, Maurice Ekpenyong ${ }^{1,2 *}$, Iquo Takon ${ }^{3}$, Sylvester Antai ${ }^{1,2}$, Nkpa Ogarekpe $^{4}$, \\ Richard Antigha ${ }^{4}$, Philomena Edet ${ }^{1}$, Agnes Antai $^{5}$ \& Joseph Essien ${ }^{6}$ \\ 1. Environmental Microbiology and Biotechnology Unit, Department of Microbiology, \\ Faculty of Biological Sciences, University of Calabar, Nigeria \\ 2. University of Calabar Collection of Microorganisms (UCCM), Department of \\ Microbiology, University of Calabar, Nigeria \\ 3. Industrial Microbiology and Biotechnology Unit, Department of Microbiology, Faculty \\ of Biological Sciences, University of Calabar, Nigeria \\ 4. Environmental Engineering Unit, Department of Civil Engineering, Faculty of \\ Engineering, Cross River University of Technology, Nigeria \\ 5. Department of Economics, Faculty of Social Sciences, University of Calabar, Nigeria \\ 6. Environmental Microbiology and Biotechnology, Department of Microbiology, Faculty \\ of Sciences, University of Uyo, Nigeria \\ *Correspondence: *ME: maurygg2002@yahoo.com; mauriceekpenyong@unical.edu.ng ; +234- \\ 70-38218972; ORCID No.: https://orcid.org/0000-0001-9601-5546
}

\begin{abstract}
Microbial fermentations for value-added metabolites production are exploited for efficient bioconversion of agroindustrial wastes for the dual purposes of pollution abatement and cost-effectiveness. In the present study, the regular 2-level factorial design was employed to screen fermentation parameters that enhance production of a novel alkaline protease by a strain of Stenotrophomonas acidaminiphila using cassava processing effluent as substrate. Data from randomized experiments of central composite rotatable design for improved enzyme activity, guided by path of steepest ascent experiments, were modeled and optimized by response surface methodology (RSM). Shake flask kinetics of production under optimized conditions was modeled by logistic and modified Gompertz models and determinations of maximum specific growth rate, $\mu_{\max }$, maximum volumetric rate of substrate consumption, $r_{\mathrm{sm}}$, maximum volumetric rate of biomass formation, $r_{\mathrm{xm}}$ and specific yield of product, $\mathrm{Y}_{\mathrm{p} / \mathrm{x}}$ were made. Logistic model poorly fitted RSM-generated product formation and substrate consumption data. However, biomass formation was accurately fitted (adjusted $r^{2}>99 \%$ ), with $\mu_{\max }$ of $0.471 \mathrm{~h}^{-1}$. The modified Gompertz model, on the contrary, more accurately fitted all three major response data with minimal mean squared error. Potential for scale-up of bioprocess evaluated in 5-L bioreactor satisfactorily revealed 8.5-fold more substrate consumption in bioreactor than in shake flask. The 86.76-fold aqueous two-phase system-purified protease had a specific activity of $1416.73 \mathrm{Umg}^{-1}$ which improved with increasing surfactant concentration. These results suggest significant bioprocess potential for sustainable cassava effluent management and concomitant commercial production of alkaline protease for industrial detergent application.
\end{abstract}

Keywords: Alkaline protease activity; Cassava processing effluent bioconversion; Stenotrophomonas acidaminiphila; Response surface optimization; Kinetic modeling; Sustainable environmental pollution abatement 


\section{Introduction}

Proteases constitute the largest enzyme market worldwide (Lazim et al. 2009) arising from the copious commercial applications and the range of proteinaeous substrates they catalyze. They are produced by all biological systems including plants, animals and microorganisms; however, commercial interest rests mostly on microbial sources by reason of their ease of production, recovery and amenability to improved productions in terms of cost and activity, in addition to demonstration of substrate diversity (Razzaq et al. 2019). Among microorganisms, bacterial proteases are the most encountered but fungal proteases are also available for commercial use. Bacterial and fungal proteases appear to have significant differences in terms of molecular weight and stability to environmental conditions of temperature, $\mathrm{pH}$ and ionic strength (Saggu and Mishra 2017). The conditions of temperature and $\mathrm{pH}$ are particularly significant in the classification of proteases and have therefore influenced their commercial applications in industries as varied as detergent, tannery, pharmaceutical, leather and environmental nitrogen cycling (Saxena and Singh 2010; Asitok et al. 2017; Ammasi et al. 2020). Mesophilic proteases are the most abundant but thermostable proteases are more suitable for specialized applications that involve high temperature processing like paper and textile processing (Abusham et al. 2009). In terms of pH discrepancy, proteases are categorized as acidic, neutral and alkaline. Alkaline and neutral proteases dominate literature while acid proteases, produced mostly by filamentous fungi, are less frequently encountered (Gupta et al. 2002; Razzaq et al. 2019; Ammasi et al. 2020).

Like every other value-added microbial product, the natural or baseline yield is usually low and costeffectiveness very poor (Ekpenyong et al. 2021a). To improve production economics, biosynthesis of one or more value-added metabolite during bioconversion of agro-industrial waste on a large scale has been suggested (Ekpenyong et al. 2017a). To improve yield and/or activity, a number of nutritional and environmental requirements of high-yielding microbial strains need to be optimized (Ekpenyong et al. 2017a, b; 2021a). Response surface methodology (RSM) and artificial neural network (ANN) methods have become gold standards for bioprocess optimizations for the dual purposes of improving yield and cost-effectiveness (Kanno et al. 2020; Ekpenyong et al. 2021a; Dwibedi et al. 2021). Response surface methodology typically has a limitation in its handling of non-linear relationships, if at all. Artificial neural network methods, on the other hand, are naturally designed to handle complicated non-linear relationships, which in microbial fermentative productions are typically stochastic. There is 
no end to reports on the superiority of one approach over the other (Karri and Sahu 2018). However, with coefficient of determination, $r^{2}$ and mean squared error (MSE) or other performance metrics, one approach could be selected ahead of the other (Lau et al. 2020). Response surface methodology typically involves four basic steps which include selection of process influencing factors using one-factor-at-a-time (OFAT) approach (Ekpenyong et al. 2017a), screening of selected process factors for just significant factors using Placket-Burman design (PBD) or any other 2-level factorial design (Ekpenyong et al. 2017b; Long et al. 2018), moving the levels of significant variables close to the region of experimentation using the path of steepest ascent (Yingling and Zhengfang 2013) and finally designing response surface experiments using any of central composite or Box-Benkhen designs to locate the actual region of interest (Karri and Sahu 2018; Ekpenyong et al. 2021b).

Time-related changes in bioconversion and simultaneous production of value-added biotechnological products are of utmost consideration in deciding bioprocess economics. The need for speed from industry to market becomes necessary for improved turn-over of bioprocesses (Truppo 2017; Boshagh and Rostami 2021). Microbial process turn-over is inherently determined by the growth rate of the transforming microorganism which is substratespecific. Kinetic studies reveal latent parameters of bioprocesses that are amenable to optimization. Such parameters as volumetric substrate consumption or conversion rates are particularly significant in environmental engineering technologies that remove contaminants from test systems (Salahi et al. 2013; Ekpenyong et al. 2021c). Bioconversion kinetics are usually confirmed by established or newly proposed models which are useful to predict future performances in similar systems. Very frequently in microbial bioconversions, the transforming microorganism uses the substrate as carbon or energy source, thus making determinations of such parameters as length of lag phase, maximum specific growth rate, volumetric and/or specific productivities sacrosanct. The Monod, Logistic, modified Gompertz and Luedeking-Piret models are a few of the models that have been developed to tackle environmental and industrial bioconversion kinetic problems (Mercier et al 1992; Tjørve and Tjørve 2017; Sulieman et al. 2018).

The bacterium Stenotrophomonas acidaminiphila UCCM 00065 was found to produce an alkaline caseinolytic protease with $\mathrm{pH}$ optimum of 9.0 at a temperature optimum of $40^{\circ} \mathrm{C}$ (Edet et al. 2018). An activity of $153 \mathrm{U}$ was reported under un-optimized conditions. In the present study, RSM was used to optimize bioprocess variables selected by statistical methods towards improved production of the alkaline protease during bioconversion 
of cassava processing effluent by the bacterium. Authors are not aware of any prior report(s) that describe(s) optimized alkaline protease production by this bacterium, or the promise it holds for environmental pollution abatement.

\section{$2 \quad$ Materials and methods}

\subsection{The microorganism}

Stenotrophomonas acidaminiphila UCCM 00065 was isolated by Edet et al. (2018) from a local fermenting bean processing effluent in Calabar, Nigeria and identified by 16S rRNA gene partial sequencing as a Gramnegative bacterial strain with $100 \%$ sequence homology with Stenotrophomonas acidaminiphila strain YF-S2 (accession number: KF305533.1). The bacterium was deposited with the University of Calabar Collection of Microorganisms (UCCM) and preserved as a $-80^{\circ} \mathrm{C}$ glycerol-frozen stock $\left(20 \%\left[\mathrm{wv}^{-1}\right]\right.$ glycerol $/ 2 \%\left[\mathrm{wv}^{-1}\right]$ peptone). A vial containing stocked bacterium was retrieved from the culture collection, reactivated and quality checked according to collection's guidelines (www.wfcc.info/ccinfo/collection/by id/652). The phylogenetic tree of the bacterium showing closely related species is presented as Figure 1.

\subsection{Regular two-level factorial screening of variables for improved protease production}

One-factor-at-a-time (OFAT) screening of carbon, nitrogen and phosphorus sources for improved alkaline protease production by the bacterium selected the primary substrate cassava processing effluent (CPE), casein, corn steep liquor and $\mathrm{K}_{2} \mathrm{HPO}_{4} / \mathrm{KH}_{2} \mathrm{PO}_{4}(2: 1)$ (Edet et al. 2018) as significant major influencing variables for alkaline protease production by the bacterium. Additional factors included in the screening were cations including $\mathrm{Na}^{+}, \mathrm{K}^{+}$, $\mathrm{Mg}^{2+}, \mathrm{Ca}^{2+}, \mathrm{Zn}^{2+}, \mathrm{Co}^{2+}, \mathrm{Mn}^{2+}, \mathrm{Cu}^{2+}, \mathrm{Ni}^{2+}, \mathrm{Fe}^{2+}, \mathrm{Fe}^{3+}$ and $\mathrm{Cr}^{3+}$. The regular two-level factorial design (2-LFD) was chosen to screen these 16 factors for inclusion in a medium formulation to enhance alkaline protease production by the bacterium. The design matrix was developed in Design Expert software version 12 with each factor tested at either high $(+1)$ or low $(-1)$ levels. Results of the $2^{\mathrm{k}}$ factorial experiments were analyzed by ANOVA model and significant adjusted and predicted $r^{2}$ values charted the course for future experimentation and conclusion. Protease activity was the only response variable and was determined as described in Edet et al. (2018). One unit of protease was defined as the amount of crude enzyme that was needed to digest $1 \mathrm{mg}$ of azocasein in 1 min under assay conditions. Coefficients of significant main effects of the obtained regression equation were employed to explore the 
path of steepest ascent experiment. The regular 2-LFD equation for enzyme activity as response variable takes the form expressed as equation 1

$$
y=b_{0}+\sum b_{i} x_{i}+\sum b_{i j} \sum x_{i} x_{j}+\varepsilon \quad \text { Eqn } 1
$$

where $y$ is protease activity, $b_{0}$, a constant term, $b_{\mathrm{i}}$, the coefficient of the linear term and and $b_{\mathrm{ij}}$ coefficient of interaction term, $x_{\mathrm{i}}$ and $x_{\mathrm{j}}$ the investigated variables and $\varepsilon$ the error term.

\subsection{Steepest ascent experimentation}

The path of steepest ascent (PSA) was conducted as an intermediary experimentation to move variable conditions as close as possible to the experimental region within the design space. Coefficients of significant factor effects in the first-order model of the regular 2-LFD were employed to calculate step sizes for the PSA (Ekpenyong et al. 2021b). The slope was first calculated using the variable with the largest absolute coefficient, then the coded step sizes were converted into natural variables using the relationship between coded and natural units and the natural step change of the variable with the highest coefficient. A total of 8 PSA experiments were then conducted using the values obtained from the determined step sizes for each of the variables. The point of steepest ascent was scored as the experiment that recorded highest protease activity beyond which activity gradually decreased. Experiments were compared using ordinary one-way ANOVA in GraphPad Prism 8.4.3 and significant means separated by Tukey's HSD multiple comparisons test at $95 \%$ confidence interval.

\subsection{Central composite design of experiment (DoE) and response optimization}

A central composite rotatable design (CCRD) matrix was adopted to investigate the significant linear effects obtained from the regular 2-LFD with levels of factors guided by the step sizes suggested by the PSA. Table 1 presents the factor codes as well as actual levels calculated from step sizes from PSA. A quadratic function of a response surface method (RSM) was employed to investigate the effects of the designed variables and their levels, with contour and surface plots as pictorial representations. Analysis of variance of the multiple regression data for the response variable was used to compare data variability. Coefficients of significant model parameters were employed to build regression model using the method of least squares. The second-order function of the CCRDRSM took the form below: 
Table 1 Actual variable names, codes, units and levels of a central composite rotatable design (CCRD) for a Min-Run-Res V fractional factorial experiment

\begin{tabular}{cccccccc}
\hline & & & \multicolumn{5}{c}{ Actual levels } \\
\cline { 5 - 8 } Variable name & Code & Unit & -1.732 & -1 & 0 & +1 & +1.732 \\
\hline Cassava processing effluent (CPE) & $x_{1}$ & $\%$ & 32.5 & 33.75 & 35.00 & 36.25 & 37.5 \\
Corn steep liquor (CSL) & $x_{2}$ & $\%$ & 19.74 & 20.34 & 20.94 & 21.54 & 22.14 \\
Casein & $x_{3}$ & $\%$ & 6.42 & 6.6 & 6.78 & 6.96 & 7.14 \\
Temperature & $x_{4}$ & ${ }^{\circ} \mathrm{C}$ & 29.84 & 30.27 & 30.70 & 31.13 & 31.56 \\
Ionic strength (IS) & $x_{5}$ & $\mathrm{M}$ & 1.67 & 1.73 & 1.79 & 1.85 & 1.91 \\
Magnesium ions (Mgenyyyyyyy Zinc ions $\left(\mathrm{Zn}^{2+}\right)$ & $x_{6}$ & $\mathrm{~g} / \mathrm{L}$ & 0.35 & 0.365 & 0.38 & 0.395 & 0.41 \\
Nickel ions $\left(\mathrm{Ni}^{2+}\right)$ & $x_{7}$ & $\mathrm{mg} / \mathrm{L}$ & 30.052 & 30.881 & 31.71 & 32.539 & 33.368 \\
Iron (II) ions $\left(\mathrm{Fe}^{2+}\right)$ & $x_{8}$ & $\mathrm{mg} / \mathrm{L}$ & 35.32 & 35.71 & 36.10 & 36.49 & 36.88 \\
& $x_{9}$ & $\mathrm{mg} / \mathrm{L}$ & 15.662 & 17.692 & 19.72 & 21.748 & 23.776 \\
\hline
\end{tabular}




$$
y=\beta_{0}+\sum_{i=1}^{k} \beta_{i} x_{i}+\sum_{i=1}^{k} \beta_{i i} x_{i}^{2}+\beta_{i j} x_{i} x_{j}+\varepsilon \quad \text { Eqn } 2
$$

where $\mathrm{y}$ is protease activity, $\beta_{0}, \beta_{i}, \beta_{i i}$ and $\beta_{i j}$ are coefficients of the constant, linear $\left(x_{\mathrm{i}}\right)$, quadratic $\left(x_{\mathrm{i}}^{2}\right)$ and interaction terms $\left(x_{\mathrm{i}} x_{\mathrm{j}}\right)$ of the $k$ factors respectively, with $\varepsilon$ as error term of computation of protease activity. Model performance was evaluated with adjusted and predicted $r^{2}$ values, as well as lack-of-fit error probability.

The response optimizer in Design Expert 12 was employed to optimize variable conditions using the desirability function and parameter importance with regression model of the CCRD as fitness function. Except cassava processing effluent (CPE), all other variables were left at 'in range' mode while goal or response variable (protease activity) was set as 'maximize'. Maximum level of importance was also assigned to both CPE and protease activity.

\subsection{Confirmation experiment}

The optimum variable conditions suggested by CCRD-RSM optimization were employed to set up a fresh fermentation in 1-L Erlenmeyer flask. Experimental set up was in triplicates and enzyme activities determined as previously described (Edet et al. 2018). A difference of less than 5\% in protease activities between optimized factor settings and real-life situation at the optimized variable conditions ratified the model as fitting for future predictions of protease production by the bacterium using cassava processing effluent as substrate.

\subsection{Shake flask kinetics of fermentative protease production under optimized conditions}

\subsubsection{Seed bacterial inoculum preparation}

Seed culture for fermentation was developed in a basal medium containing $\left(\mathrm{gL}^{-1}\right) 1.5 \mathrm{Na}_{2} \mathrm{HPO}_{4} / \mathrm{KH}_{2} \mathrm{PO}_{4}$ $(2: 1) ; 0.5 \mathrm{NaCl} ; 0.5 \mathrm{CaCl}_{2} ; 0.15 \mathrm{KCl} ; 0.0104$ boron; $0.025 \mathrm{CuSO}_{4} .5 \mathrm{H}_{2} \mathrm{O} ; 0.001 \mathrm{CoCl}_{2}$ and $0.001 \mathrm{MnCl}_{2}$, at nonsignificant sub-optimal levels. Significant minerals including $\mathrm{Mg}^{2+} ; \mathrm{Ni}^{2+}, \mathrm{Zn}^{2+}, \mathrm{Fe}^{2+}$ were added at optimized levels suggested by CCRD-RSM experimentation and medium augmented for optimum growth with $0.1 \mathrm{gL}^{-1} \mathrm{casamino}$ acid. Ionic strength was adjusted to optimized level using the weakly coordinating anion, $\mathrm{NaClO}_{4}$. The medium was supplemented with $3 \%\left(\mathrm{vv}^{-1}\right)$ cassava processing effluent, $1 \%\left(\mathrm{wv}^{-1}\right)$ corn steep liquor and $1 \%\left(\mathrm{wv}^{-1}\right)$ casein as enzyme substrate. Medium $\mathrm{pH}$ was adjusted to $7.0 \pm 0.2$ and medium sterilized at $121^{\circ} \mathrm{C}$ for 15 min. Cooled medium was inoculated with $2 \%\left(\mathrm{vv}^{-1}\right)$ of 18 -h old trypticase soy bacterial broth culture. Incubation was at $30^{\circ} \mathrm{C}$ on an orbital 
shaker operating at $150 \mathrm{rpm}$ until $1.5 \times 10^{8}$ cellsmL $\mathrm{sm}^{-1}$ density, monitored spectrophotometrically as $\mathrm{OD}_{600}$ was reached. This was repeated three times, through 2-fold dilution with fresh broth. Culture broth from the third passage was then employed as seed inoculum for fermentative production of the alkaline protease.

\subsubsection{Fermentation kinetics study}

Experimental set up was as described in Ekpenyong et al. (2021c) except for a few modifications. Briefly, triplicate bench-scale batch-mode fermentation was set up in 1-L Erlenmeyer flask equipped with side arm, with a working volume of $200 \mathrm{~mL}$. The fermentation medium was as described for inoculum development in section 2.6.1 except that CPE, CSL and the enzyme substrate, casein were added at their suggested optimized levels. The CPE was composed $\left(\mathrm{gL}^{-1}\right)$ of TSS 2.98; $\mathrm{COD} 8.73$ BOD $_{5} 3.20$; total carbohydrates 191.64, starch 115.46; reducing sugars 65.12 ; ammonium nitrogen 0.036 ; total nitrogen 0.27 ; phosphates 0.031 . The composition of corn steep liquor was as reported in Ekpenyong et al. (2021b). Ionic strength of medium was adjusted to optimized level using $\mathrm{NaClO}_{4}$. Medium $\mathrm{pH}$ was adjusted to 7.0 before autoclaving at $121^{\circ} \mathrm{C}$ for $15 \mathrm{~min}$. Initial reducing sugar concentration was determined after sterilization by Cooled medium was inoculated with $2 \%\left(\mathrm{vv}^{-1}-1.58 \times 10^{8} \mathrm{cfumL}^{-}\right.$ ${ }^{1}$ ) of 18-h old seed culture from section 2.6.1 and triplicate flasks incubated at optimized temperature on a rotary shaker adjusted to agitate at $200 \mathrm{rpm}$ for $36 \mathrm{~h}$.

\subsubsection{Determination of fermentation response variables}

Periodically, at $4 \mathrm{~h}$ interval, $5 \mathrm{~mL}$ of sample was withdrawn from triplicate flasks and centrifuged at 10,000 $\mathrm{x} g$ for $5 \mathrm{~min}$ and determinations of total protein, protease activity, biomass concentration and amount of substrate consumed made from appropriate fractions.

Total protein was determined from sterile supernatant post-centrifugation by the Bradford method of determination of microgram quantities of protein (Asitok et al. 2017) using bovine serum albumin as standard protein and coomasie brilliant blue dye as protein reagent. Triplicate determinations were obtained with the regression equation of the standard curve: $T P=\left(O D_{595}-0.7533\right) / 0.0109 ; R^{2}=0.9934$.

Protease activity was determined as described by Edet et al. (2018) using azocasein as substrate and protease activity defined as in section 2.2 . 
Biomass was quantified by the dry cell weight (DCW) technique (Rodrigues et al. 2006) from the pellet obtained from centrifugation at $10,000 \mathrm{x} g$ for $5 \mathrm{~min}$. Biomass concentration $\left(\mathrm{gL}^{-1}\right)$ was given by the regression equation that established the relationship between dry cell weight (DCW) and optical density at $600 \mathrm{~nm}$ as given by the equation $D C W=\left(O D_{600} \times 0.633\right)+0.031 ; r^{2}=0.9984$.

Amount of substrate consumed was calculated by first determining residual reducing sugar at time $t \mathrm{~h}$ using the DNS assay (Miller 1959) with glucose (Merck, USA) as standard carbohydrate and then subtracting the result from the initial amount at time $0 \mathrm{~h}$. The regression equation for the relationship between glucose concentration and optical density was given by the expression $O D_{540}=0.023 x+0.0282 ; r^{2}=0.9991$.

Triplicate time-related response data were subjected to descriptive statistics to obtain mean parameters $+/$ standard error. Means were compared by one-way ANOVA and significant means separated by Tukey's HSD posthoc multiple comparisons test using $95 \%$ confidence interval.

\subsection{Kinetic model-fitting of experimental data and model-performance evaluation}

Mean data for the three major responses of biomass formation, protease activity and substrate consumption were fitted to the modified Gompertz and logistic models (Ekpenyong et al. 2021c) to ascertain which would better explain the data or whether a new model would have to be proposed. Equation 3 describes the logistic models for biomass formation;

$$
\frac{d X}{d t}=\mu_{\max } X\left(1-\frac{X}{X_{\max }}\right) \quad \text { Eqn } 3
$$

where $X$ is biomass concentration $(\mathrm{g} / \mathrm{L})$ at any time $t, X_{0}$ is the initial biomass concentration at time $t_{0}, X_{\max }$ is maximum biomass concentration $(\mathrm{g} / \mathrm{L}), \mu_{\max }$ is the maximum specific growth rate $\left(\mathrm{h}^{-1}\right), S$ is the amount of substrate consumed, $S_{0}$ is the substrate concentration at time $\mathrm{t}_{0}$.

The modified Gompertz model equations are presented as equations 4, 5 and 6 for biomass formation, protease activity and substrate consumption respectively.

$$
X=X_{\max } \exp \left(-\exp \left(\frac{e \cdot r_{x \max }}{X_{\max }}\left(t_{\text {lag }}-t\right)+1\right)\right) \quad \text { Eqn } 4
$$




$$
\begin{aligned}
& P=P_{\text {max }} \exp \left(-\exp \left(\frac{e \cdot r_{\text {max }}}{P_{\text {max }}}\left(t_{\text {lag }}-t\right)+1\right)\right) \quad \text { Eqn } 5 \\
& S=S_{\text {max }} \exp \left(-\exp \left(\frac{e \cdot r_{\text {smax }}}{S_{\text {max }}}\left(t_{\text {lag }}-t\right)+1\right)\right) \quad \text { Eqn } 6
\end{aligned}
$$

where $X, P$ and $S$ are biomass, protease activity and amount of substrate consumed at any time of fermentation, $t$; $X_{\max }$ and $P_{\max }$ are maximum biomass concentrations $(\mathrm{g} / \mathrm{L})$ and maximum protease activity, $S_{\max }$ is the potential drop in substrate concentration; $r_{\mathrm{x} \max }$ and $r_{\mathrm{pmax}}$ (g/L.h) are maximum biomass and biosurfactant formation rates and $r_{\mathrm{smax}}$ is the maximum rate of substrate consumption $(\mathrm{g} / \mathrm{L} . \mathrm{h}) ; t_{\text {lag }}$ is the lag time $(\mathrm{h})$ defined as the time to reach exponential biomass formation, protease activity and exponential substrate consumption.

Kinetic parameters were obtained in triplicates and results reported as mean values $+/$ - standard error. Model performances were evaluated using coefficient of determination, $r^{2}$, mean squared error (MSE) and mean absolute error (MAE) (Ekpenyong et al. 2021a), using the expressions in equations 7, 8 and 9 respectively.

$$
\begin{gathered}
R^{2}=1-\frac{\sum_{i=1}^{n}(y-\hat{y})^{2}}{\sum_{i=1}^{n}(y-\bar{y})^{2}} \\
M S E=\frac{1}{n} \sum_{i=1}^{n}(y-\hat{y})^{2} \\
M A E=\frac{1}{n} \sum_{i=1}^{n}|\hat{y}-y|
\end{gathered}
$$

where $n$ is the number of samples, $y$ and $\hat{y}$ the actual value and predicted values respectively.

\subsection{Scale-up of fermentative alkaline protease production in 5-L bioreactor}

Batch mode fermentation of cassava processing effluent by Stenotrophomonas acidaminiphila UCCM 00065 under optimized conditions was also conducted in a 5-L bench-scale bioreactor (BioStat, Sartorius) with a working volume of $3.5 \mathrm{~L}$. The medium had the same composition as that used in the shake flask experiment. Temperature was maintained at the CCRD-RSM optimized level while $\mathrm{pH}$, agitation speed and dissolved oxygen were maintained at $7.0 \pm 0.2,150 \mathrm{rpm}$ and $50 \%$ respectively. Filter-sterilized air was allowed to flow into the headspace of the vessel at a rate of $1 \mathrm{~L} / \mathrm{min}$ controlled by a mass flow controller. The bioreactor was equipped with a single in-place sterilization mechanism. The vessel, allowed to cool near optimized temperature after sterilization, 
was inoculated, through culture inlet, with $2 \%(\mathrm{v} / \mathrm{v})$ of overnight seed bacterial culture as in the shake flask experiment and reactor operated batch-mode for 4 to $36 \mathrm{~h}$. Each batch of fermentation was set up in triplicates. Determinations of total protein, total enzyme activity, biomass concentration and residual total carbohydrate were made as earlier described in section 2.6.3. Once again, data was modeled by means of the logistic and modified Gompertz models to determine lag time, maximum specific growth rate, specific and volumetric substrate consumption rates, and volumetric rates of product and biomass formation under bioreactor conditions to compare with kinetic parameters obtained from shake flask studies.

\subsection{Purification of Stenotrophomonas acidaminiphila UCCM 00065 alkaline protease by aqueous two-phase system}

Polyethylene glycol-sodium citrate $\left(\mathrm{PEG}-\mathrm{Na}^{+} \mathrm{Citrate}\right)$ system was employed for aqueous two-phase system separation and purification of the enzyme. Five different sizes (molecular weights) of the PEG including 1500, 3000, 4500, 6000 and 7500 were investigated. The component phase systems were constituted by $\% \mathrm{w} / \mathrm{w}$ in a $15 \mathrm{~mL}$ graduated centrifuge tube. Total mixture of polymer, water, sodium citrate and $2 \%$ crude enzyme in the tube was $100 \%$. Separation was conducted at different $\mathrm{pH}$ levels of sodium citrate; $\mathrm{pH} 7.5,8.5$ and 9.5 and holding temperatures namely 20,35 and $50^{\circ} \mathrm{C}$. At each separation condition, the mixture was centrifuged at $3000 \mathrm{rpm}$ for 20 min to facilitate phase separation and tube held at $20^{\circ} \mathrm{C}$ for $24 \mathrm{~h}$ for equilibration (Abd Samad et al. 2017). Total protein and total enzyme activity were determined at each separation condition and results used to calculate specific activity of the enzyme, yield and extent (fold) of purification.

\subsection{Stability evaluation of purified alkaline protease to surfactants}

The stability of purified alkaline protease was evaluated by pre-incubating the enzyme with sodium dodecyl sulfate (SDS), triton X-100 and Tween 80 each at 1, 5 and $10 \mathrm{mM}$ before repeating protease assay using azocasein as substrate. Stability to each denaturant was evaluated in triplicates by calculating the relative activity of the enzyme and data analyzed using two-way ANOVA in GraphPad Prism 8.4.3 software. 


\section{Results}

\subsection{Phylogeny of Stenotrophomonas acidaminiphila UCCM 00065}

The phylogenetic tree of the producing bacterium Stenotrophomonas acidaminiphila UCCM 00065 is presented as Figure 1.

\subsection{Regular 2-level factorial design screening experiment}

The results of the regular 2-level factorial design (2-LFD) experiments are presented in Table 2 into which percent contributions of each model parameter has been highlighted. The table reveals that cassava processing effluent (CPE) had the largest significant effect (13.10\%) on protease activity followed by ionic strength (12.22\%). Other significant linear contributors to the final protease activity of $1236.34 \mathrm{U}$ (predicted as $1249.28 \mathrm{U}$ ) were $\mathrm{Fe}^{2+}$ (8.63\%) and corn seep liquor (CSL-8.23\%). Highly significant interaction factors were CPE/Zn ${ }^{2+}(11.47 \%)$, $\mathrm{CPE} / \mathrm{Ni}^{2+}(9.76 \%)$ and $\mathrm{CPE} /$ Agitation $(9.18 \%)$. Cobalt (II) ion $\left(\mathrm{Co}^{2+}\right)$ was completely eliminated from the model and the modified equation for the 2-LFD is presented as equation 12.

Protease activity

$$
\begin{aligned}
& =864.090+63.526 \mathrm{CPE}+50.336 \mathrm{CSL}+22.616 \text { Casein }-6.617 \text { Phosphates } \\
& -21.854 \text { Temperature }-6.858 \mathrm{pH}-61.351 \text { Ionic strength }-0.291 \text { Agitation }-3.259 \mathrm{~K}^{+} \\
& -16.629 \mathrm{Mg}^{2+}+2.669 \mathrm{Ca}^{2+}-21.063 \mathrm{Zn}^{2+}+3.751 \mathrm{Mn}^{2+}-9.920 \mathrm{Ni}^{2+}-51.544 \mathrm{Fe}^{2+} \\
& +14.668 \mathrm{CPE} * \text { casein }+28.909 \mathrm{CPE} * \text { phosphates }+22.416 \mathrm{CPE} * \text { temperature } \\
& +49.576 \mathrm{CPE} * p H-13.466 \mathrm{CPE} * \text { ionic strength }-53.181 \mathrm{CPE} \\
& * \text { agitation } \quad \text { Eq. } 10
\end{aligned}
$$

The model was significant at $p=0.0002<0.001$ with an adjusted $r^{2}$ of $98.86 \%$ and predicted $r^{2}$ of 90.62 .

\subsection{Path of steepest ascent experimentation}

The results of the method of steepest ascent (PSA) are illustrated in Figure 2 and reveal that each successive experiment led to significant $(p<0.05)$ increase in protease activity until the $6^{\text {th }}$ experiment where the highest protease activity of $4707.22 \mathrm{U}$ was obtained beyond which protease activity gradually decreased. The levels of the nine factors that yielded the highest protease activity were 5.0, 3.96, 1.78, $-1.72,-4.83,-1.23,-1.66,-0.78$ and 


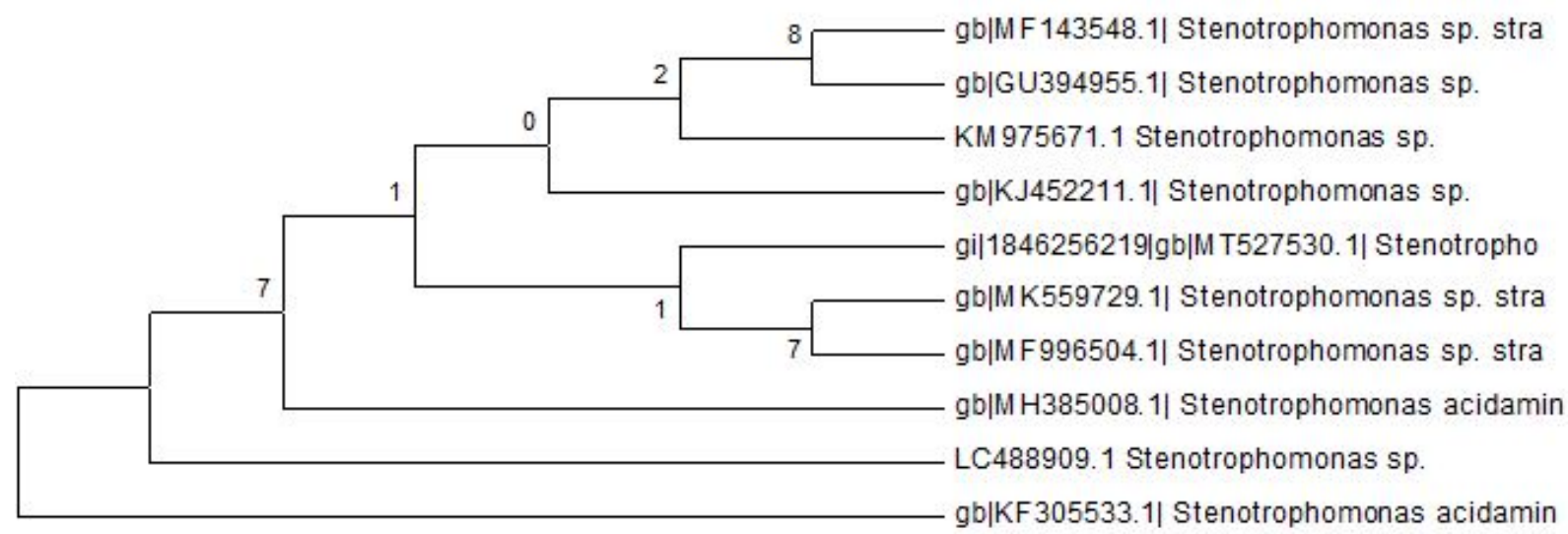

Fig. 1 Un-rooted rectangular phylogenetic tree of Stenotrophomonas acidaminiphila UCCM 00065 constructed by the method of neighbor-joining. It shows the relative position of KF305533.1 (study bacterium) in comparison to first reference strains obtained upon NCBI- BLAST. The $\%$ of replicate trees in which the associated species are clustered together in the bootstrap test of 500 replicates is shown next to the branches. 
Table 2 ANOVA and per cent contributions of factors from regular 2-level factorial screening for significant factors towards enhanced alkaline protease production

\begin{tabular}{|c|c|c|c|c|c|c|}
\hline Source & $\begin{array}{l}\text { Sum of } \\
\text { squares }\end{array}$ & $\mathrm{df}$ & Mean square & $F$-value & $p$-value & $\%$ contribution \\
\hline Model & $9.84 \mathrm{E}+05$ & 27 & 36452.67 & 100.93 & 0.0002 & \\
\hline $\mathrm{A}-\mathrm{CPE}$ & $1.29 \mathrm{E}+05$ & 1 & $1.29 \mathrm{E}+05$ & 357.56 & $<0.0001$ & 13.1017 \\
\hline B-CSL & 81079.62 & 1 & 81079.62 & 224.49 & 0.0001 & 8.22587 \\
\hline C-Casein & 16366.93 & 1 & 16366.93 & 45.32 & 0.0025 & 1.66049 \\
\hline D-Phosphates & 1401.06 & 1 & 1401.06 & 3.88 & 0.1202 & 0.142143 \\
\hline E-Temperature & 15283.64 & 1 & 15283.64 & 42.32 & 0.0029 & 1.55059 \\
\hline F-pH & 1505.08 & 1 & 1505.08 & 4.17 & 0.1108 & 0.152697 \\
\hline G-Ionic strength & $1.20 \mathrm{E}+05$ & 1 & $1.20 \mathrm{E}+05$ & 333.49 & $<0.0001$ & 12.2196 \\
\hline H-Agitation & 2.71 & 1 & 2.71 & 0.0075 & 0.9351 & 0.000275392 \\
\hline $\mathrm{J}-\mathrm{K}^{+}$ & 339.82 & 1 & 339.82 & 0.9409 & 0.387 & 0.0344764 \\
\hline $\mathrm{K}-\mathrm{Mg}^{2+}$ & 7816.88 & 1 & 7816.88 & 21.64 & 0.0096 & 0.793055 \\
\hline $\mathrm{L}-\mathrm{Ca}^{2+}$ & 227.91 & 1 & 227.91 & 0.631 & 0.4714 & 0.0231225 \\
\hline $\mathrm{M}-\mathrm{Zn}^{2+}$ & 14196.13 & 1 & 14196.13 & 39.31 & 0.0033 & 1.44026 \\
\hline $\mathrm{N}-\mathrm{Mn}^{2+}$ & 450.3 & 1 & 450.3 & 1.25 & 0.3267 & 0.0456848 \\
\hline $\mathrm{O}-\mathrm{Ni}^{2+}$ & 3149 & 1 & 3149 & 8.72 & 0.0419 & 0.31948 \\
\hline $\mathrm{P}-\mathrm{Fe}^{2+}$ & 85018.32 & 1 & 85018.32 & 235.4 & 0.0001 & 8.62546 \\
\hline $\mathrm{AC}$ & 6884.92 & 1 & 6884.92 & 19.06 & 0.012 & 0.698504 \\
\hline $\mathrm{AD}$ & 26744.06 & 1 & 26744.06 & 74.05 & 0.001 & 2.7133 \\
\hline $\mathrm{AE}$ & 16078.73 & 1 & 16078.73 & 44.52 & 0.0026 & 1.63125 \\
\hline $\mathrm{AF}$ & 78647.76 & 1 & 78647.76 & 217.76 & 0.0001 & 7.97914 \\
\hline $\mathrm{AG}$ & 5802.34 & 1 & 5802.34 & 16.07 & 0.016 & 0.588671 \\
\hline $\mathrm{AH}$ & 90503.85 & 1 & 90503.85 & 250.59 & $<0.0001$ & 9.18199 \\
\hline $\mathrm{AJ}$ & 6990.35 & 1 & 6990.35 & 19.35 & 0.0117 & 0.7092 \\
\hline $\mathrm{AK}$ & 2258.26 & 1 & 2258.26 & 6.25 & 0.0667 & 0.229109 \\
\hline $\mathrm{AL}$ & 59085.47 & 1 & 59085.47 & 163.59 & 0.0002 & 5.99447 \\
\hline $\mathrm{AM}$ & $1.13 \mathrm{E}+05$ & 1 & $1.13 \mathrm{E}+05$ & 313.12 & $<0.0001$ & 11.4733 \\
\hline $\mathrm{AO}$ & 96242.01 & 1 & 96242.01 & 266.47 & $<0.0001$ & 9.76415 \\
\hline $\mathrm{AP}$ & 5475.29 & 1 & 5475.29 & 15.16 & 0.0176 & 0.555491 \\
\hline Residual & 1444.68 & 4 & 361.17 & & & \\
\hline Cor Total & $9.86 \mathrm{E}+05$ & 31 & & & & \\
\hline$r^{2}$ & 0.9985 & & & & & \\
\hline Adjusted $r^{2}$ & 0.9886 & & & & & \\
\hline Predicted $r^{2}$ & 0.9062 & & & & & \\
\hline
\end{tabular}


-4.055 corresponding respectively to $35 \% \mathrm{CPE}, 20.94 \mathrm{~g} / \mathrm{L} \mathrm{CSL}, 6.78 \mathrm{~g} / \mathrm{L}$ casein, $30.7^{\circ} \mathrm{C}$ temperature, $1.79 \mathrm{M}$ ionic strength, $0.38 \mathrm{~g} / \mathrm{L} \mathrm{Mg}^{2+}, 31.71 \mathrm{mg} / \mathrm{L} \mathrm{Zn}^{2+}, 36.10 \mathrm{mg} / \mathrm{L} \mathrm{Ni}^{2+}$ and $19.72 \mathrm{mg} / \mathrm{L} \mathrm{Fe}^{2+}$ were employed as respective center points $(0,0,0,0,0,0,0,0,0)$ for the CCRD-RSM experiment.

\subsection{Central composite rotatable design and response surface methodology}

The results of CCRD-RSM are illustrated in Figure 3 as contour or 2-D (a) and surface or 3-D (b) plots. Only the best interactive plot, in terms of protease activity mediated, is reported here. The quadratic model of the CCRD-RSM was selected with adjusted and predicted $r^{2}$ values of $99.99 \%$ and $99.90 \%$ respectively. Lack-of-fit test result of $F(10,15)=0.3565, p=0.9224>0.05$ was not significant suggesting adequacy of the model to explain data variations about the experimental region. The plot of experimental versus predicted protease activity data is presented as Figure 4 and reveals a near-perfect fit of predicted data with experimental data. The coded regression model for protease activity was given as equation 11 below.

$$
\begin{aligned}
& Y=4635.455+ 272.234 X_{1}+97.40 X_{2}+168.952 X_{3}-115.742 X_{4}-28.347 X_{5}+111.735 X_{6}-168.793 X_{7} \\
&-82.50 X_{8}-150.604 X_{9}-19.958 X_{1} X_{2}+43.643 X_{1} X_{3}+44.118 X_{1} X_{4}+72.278 X_{1} X_{5} \\
&-5.318 X_{1} X_{6}+78.312 X_{1} X_{7}-36.652 X_{1} X_{8}-88.275 X_{1} X_{9}+173.292 X_{2} X_{3}-244.607 X_{2} X_{4} \\
&-29.867 X_{2} X_{5}+164.154 X_{2} X_{6}-124.316 X_{2} X_{7}+46.563 X_{2} X_{8}-12.099 X_{2} X_{9}-99.289 X_{3} X_{4} \\
&-88.725 X_{3} X_{5}-229.415 X_{3} X_{6}+224.056 X_{3} X_{7}-183.746 X_{3} X_{8}-107.582 X_{3} X_{9}+32.091 X_{4} X_{5} \\
&+131.602 X_{4} X_{6}-28.888 X_{4} X_{7}+127.225 X_{4} X_{8}+34.365 X_{4} X_{9}+23.750 X_{5} X_{6}-14.905 X_{5} X_{7} \\
&+189.472 X_{5} X_{8}+153.870 X_{5} X_{9}-90.389 X_{6} X_{7}-266.243 X_{6} X_{8}-177.889 X_{6} X_{9} \\
&+216.110 X_{7} X_{8}-136.405 X_{7} X_{9}-5.070 X_{8} X_{9}+21.287 X_{1}{ }^{2}-86.403 X_{2}{ }^{2}-85.203 X_{3}{ }^{2} \\
&+176.682 X_{4}{ }^{2}-51.680 X_{5}{ }^{2}-98.340 X_{6}{ }^{2}-84.413 X_{7}{ }^{2}-247.633 X_{8}{ }^{2} \\
&-93.270 X_{9}{ }^{2} \\
& E q .11
\end{aligned}
$$






Path of steepest ascent experiments

Fig. 2 Steepest ascent experiment showing the steepest point

Variable levels at steepest point were employed as center points in CCRD-RSM; * and ** are significant levels at $p=0.05$ and 0.01 respectively 
Factor Coding: Actual

\section{Protease activity (U)}

Design Points

3053.49

$\mathrm{X}_{1}=\mathrm{A}: \mathrm{CPE}$

$\mathrm{X} 2=\mathrm{B}: \mathrm{CSL}$

Actual Factors

C: Casein $=1$

D: Temp $=-1$

E: IS $=-1$

$\mathrm{F}: \mathrm{Mg} 2+=-1$

$\mathrm{G}: \mathrm{Zn} 2+=-1$

$\mathrm{H}: \mathrm{Ni} 2+=-1$

J: $\mathrm{Fe} 2+=-1$

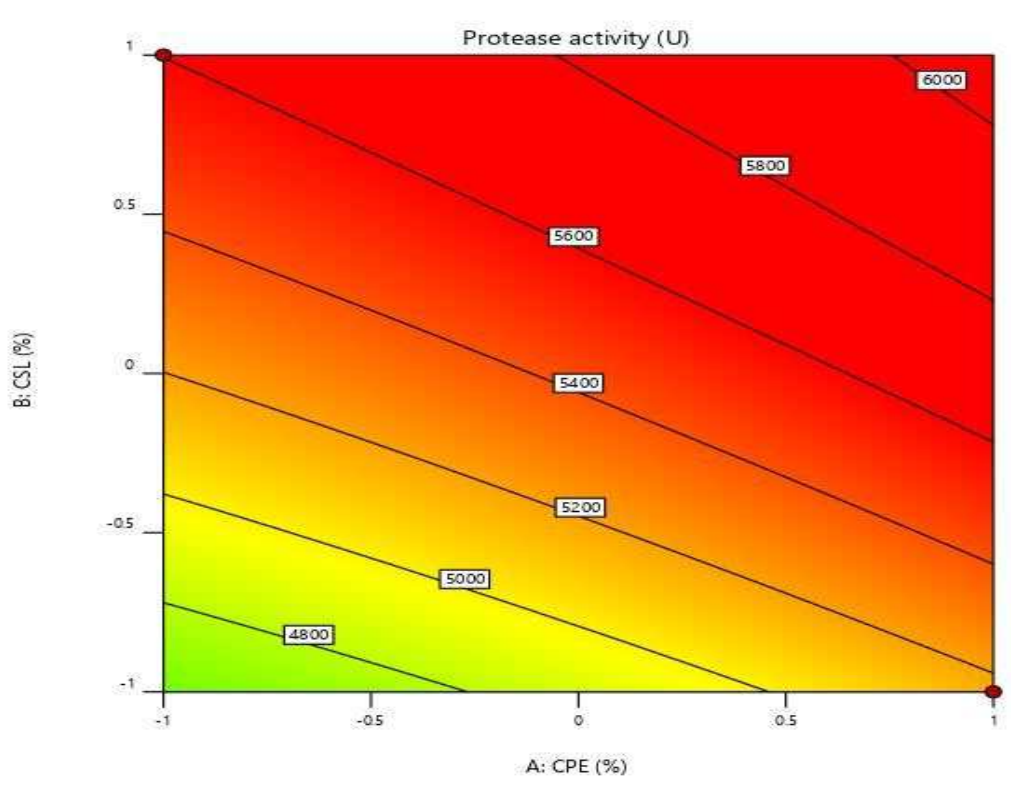

A

Factor Coding: Actual

Protease activity (U)

Design Points:

- Above Surface

Below Surface

$3053.49 \square 5602.58$
$\square \quad 5$

$\mathrm{X} 1=\mathrm{A}: \mathrm{CPE}$

$\mathrm{X} 2=\mathrm{B}: \mathrm{CSL}$

\section{Actual Factors}

C: Casein $=1$

D: Temp $=-1$

E: IS $=-1$

$\mathrm{F}: \mathrm{Mg} 2+=-1$

$\mathrm{G}: \mathrm{Zn} 2+=-1$

$\mathrm{H}: \mathrm{Ni} 2+=-1$

J: $\mathrm{Fe} 2+=-1$

3D Surface

B

Fig. 3 RSM model contour plot (A) and surface plot (B) of two-way interaction of variables towards maximum protease activity

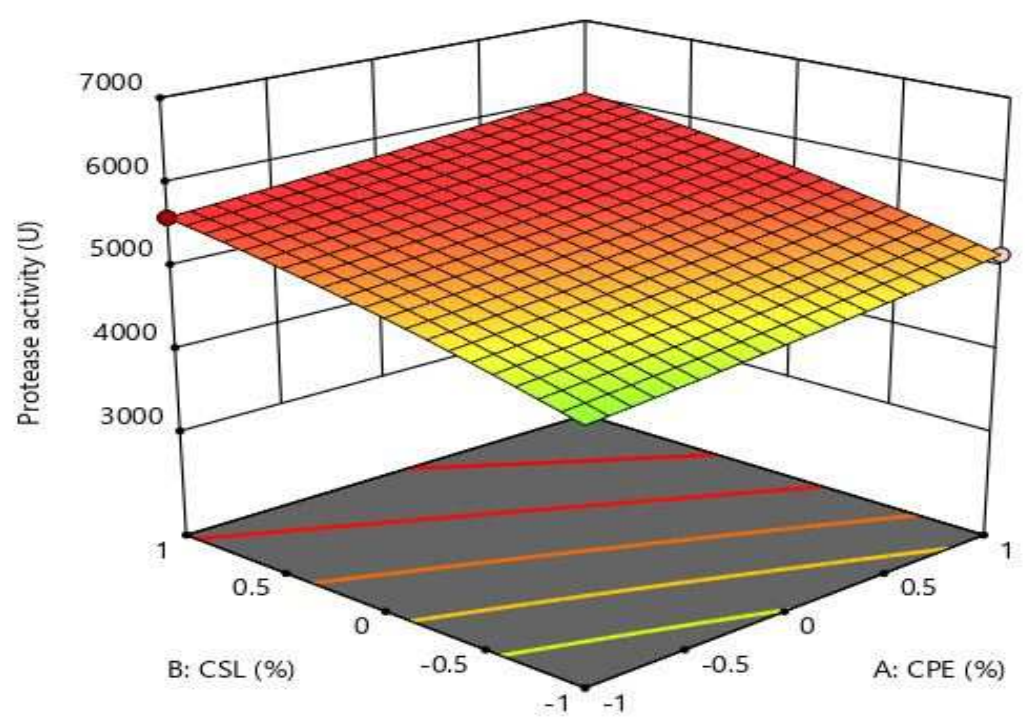




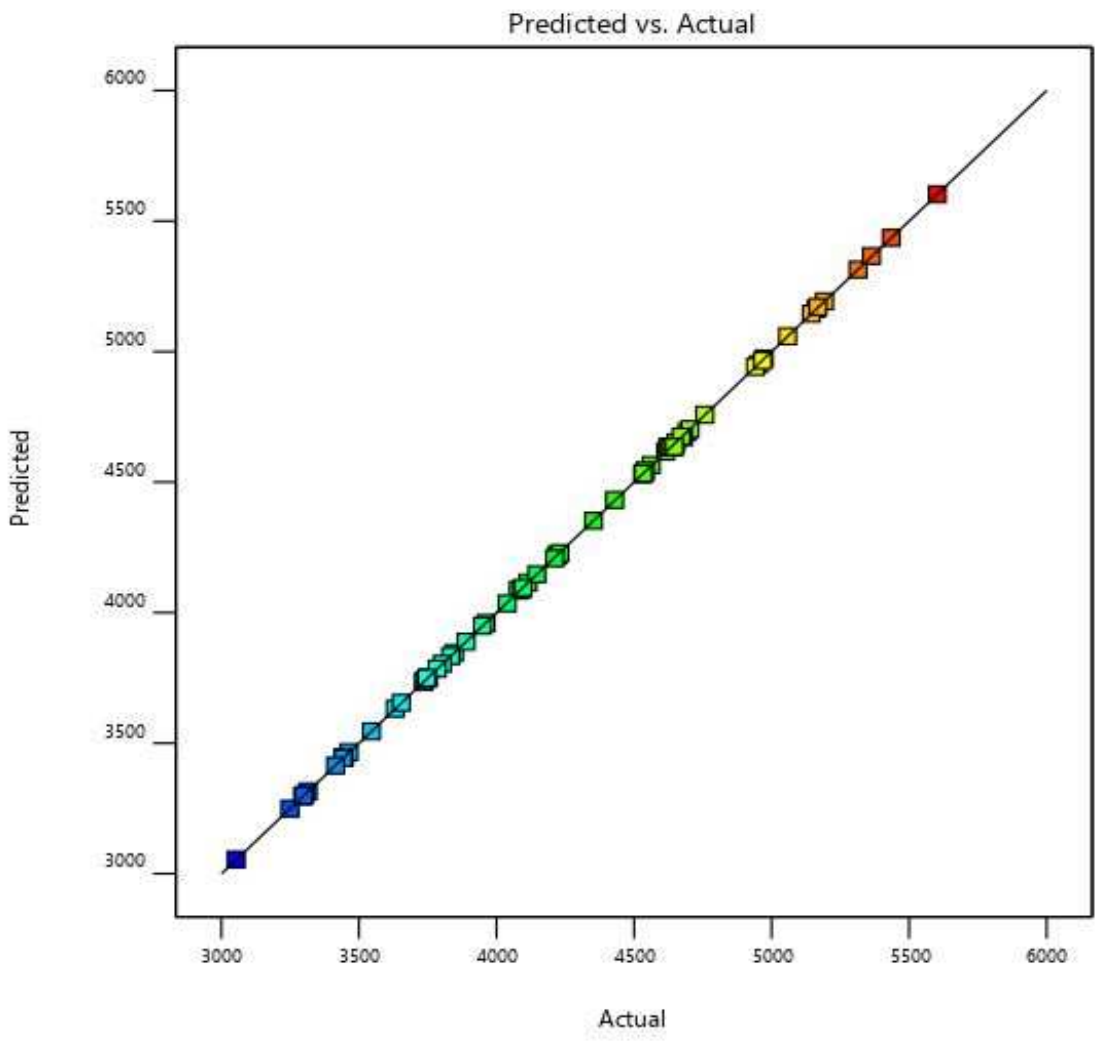

Fig. 4 Experimental versus RSM model predicted protease activity data plot 


\subsection{RSM optimization and model confirmation}

Results of the optimization experiment are illustrated in Figure 5 as 2-D (a) and 3-D (b) plots for the optimized conditions of fermentation parameters towards improved protease activity. The response optimizer revealed that if 8 input variables were allowed at their 'in range' levels and mid-level importance $(+++)$, with only cassava processing effluent (input variable) and protease activity (output variable) maximized and at their highest level of importance $(+++++)$, predicted protease activity would be $5759.57 \mathrm{U}$ if the input factors were set at optimum levels $(x, X)=($ coded, actual) of CPE $(1,36.25 \%)$, CSL $(0.887,21.47 \mathrm{~g} / \mathrm{L})$, casein $(-0.098,6.76 \mathrm{~g} / \mathrm{L})$, temperature $(-$ $\left.0.723,30.4^{\circ} \mathrm{C}\right)$, ionic strength $(-0.681,1.75 \mathrm{M}), \mathrm{Mg}^{2+}(0.538,0.39 \mathrm{~g} / \mathrm{L}), \mathrm{Zn}^{2+}(-0.968,0.031 \mathrm{~g} / \mathrm{L}), \mathrm{Ni}^{2+}(-0.716,0.036$ $\mathrm{g} / \mathrm{L})$ and $\mathrm{Fe}^{2+}(-0.189,0.019 \mathrm{~g} / \mathrm{L})$. Figure 6 is a perturbation plot of the nine input variables showing their interplay to bring about the response. In the confirmation experiment, mean protease activity obtained using the optimum settings for the significant variables from the optimization experiment was $5784.83 \pm 89.64 \mathrm{U}$ as against the $5759.57 \mathrm{U}$ protease activity of the response optimizer; some $0.045 \%$ difference showing reliability of the suggested optimum levels.

\subsection{Kinetics, model-fitting and performance evaluation}

Results of the kinetic study are illustrated as Figures 7 and 8 as well as Tables 3 and 4, and show the timerelated changes in total protein $(\mathrm{mg})$, enzyme activity $(\mathrm{U})$, biomass concentration $(\mathrm{g} / \mathrm{L})$ and substrate consumption $(\mathrm{g} / \mathrm{L})$ under shake flask (a) and 5-L bioreactor (b) conditions. In Figure 7a, exponential biomass formation and substrate consumption ended at $16 \mathrm{~h}$ with a plateau running till end of fermentation at $36 \mathrm{~h}$. However, exponential protein formation as well as enzyme activity increased until $28 \mathrm{~h}$ before they flattened out. Figure $7 \mathrm{~b}$ shows that exponential substrate consumption ended in the bioreactor $4 \mathrm{~h}$ before what obtained in shake flask experiment where $93.81 \%$ of final concentration of consumed substrate was obtained. However, exponential biomass formation continued to $16 \mathrm{~h}$ in bioreactor fermentation where $90.86 \%$ of final biomass concentration was obtained. Exponential protein formation and protease activity in the 5-L bioreactor batch fermentation ended at $16 \mathrm{~h}$ when $90.46 \%$ and $97.36 \%$ of respective responses were attained. 


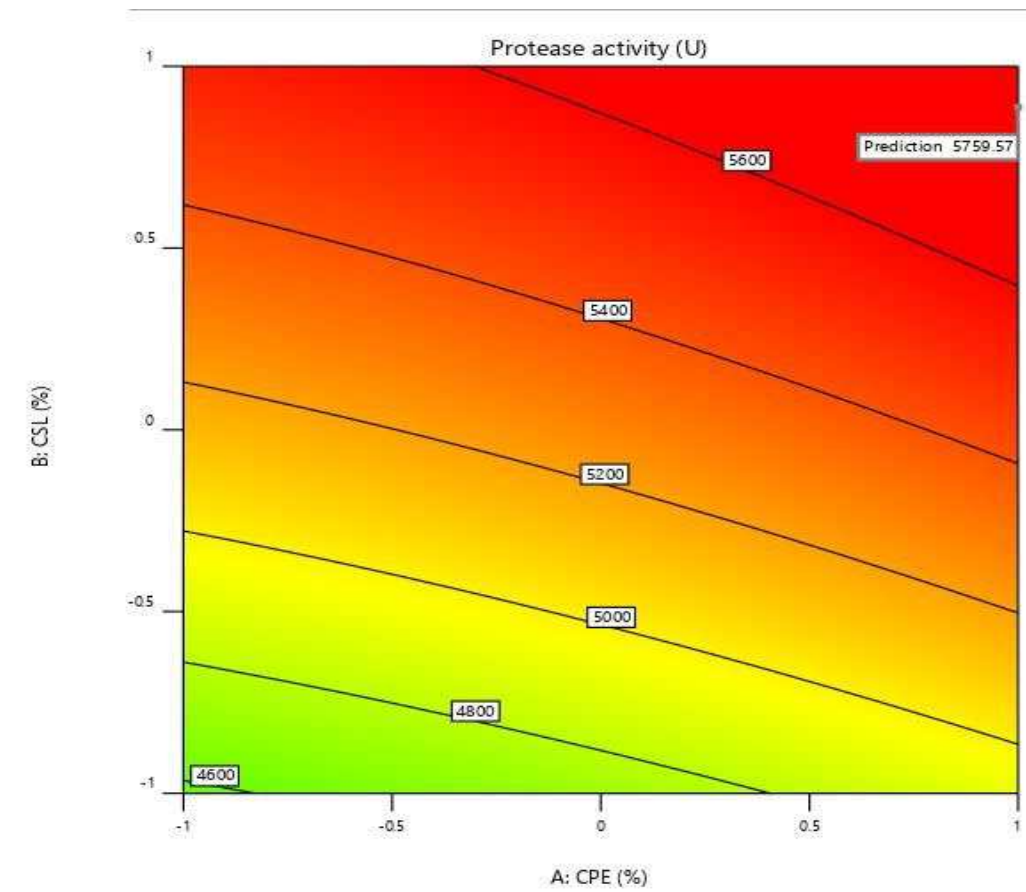

Protease activity (U)

$3053.49 \square 5602.58$

$\mathrm{X} 1=\mathrm{A}: \mathrm{CPE}$

$\mathrm{X} 2=\mathrm{B}: \mathrm{CSL}$

\section{Actual Factors}

C: Casein $=-0.0978224$

$D:$ Temp $=-0.723444$

E: IS $=-0.680595$

$\mathrm{F}: \mathrm{Mg} 2+=0.537913$

G: $\mathrm{Zn2}+=-0.96794$

$\mathrm{H}: \mathrm{Ni} 2+=-0.715924$

J: $\mathrm{Fe} 2+=-0.1894$

Factor Coding: Actual

Protease activity (U)

3D Surface

Design Points $3053.49 \square 5602.58$

$\mathrm{X} 1=\mathrm{A}: \mathrm{CPE}$

$\mathrm{X} 2=\mathrm{B}: \mathrm{CSL}$

\section{Actual Factors}

C: Casein $=-0.0978224$

D: Temp $=-0.723444$

$E:$ IS $=-0.680595$

$\mathrm{F}: \mathrm{Mg} 2+=0.537913$

$\mathrm{G}: \mathrm{Zn} 2+=-0.96794$

$\mathrm{H}: \mathrm{Ni2}+=-0.715924$

J: $\mathrm{Fe} 2+=-0.1894$

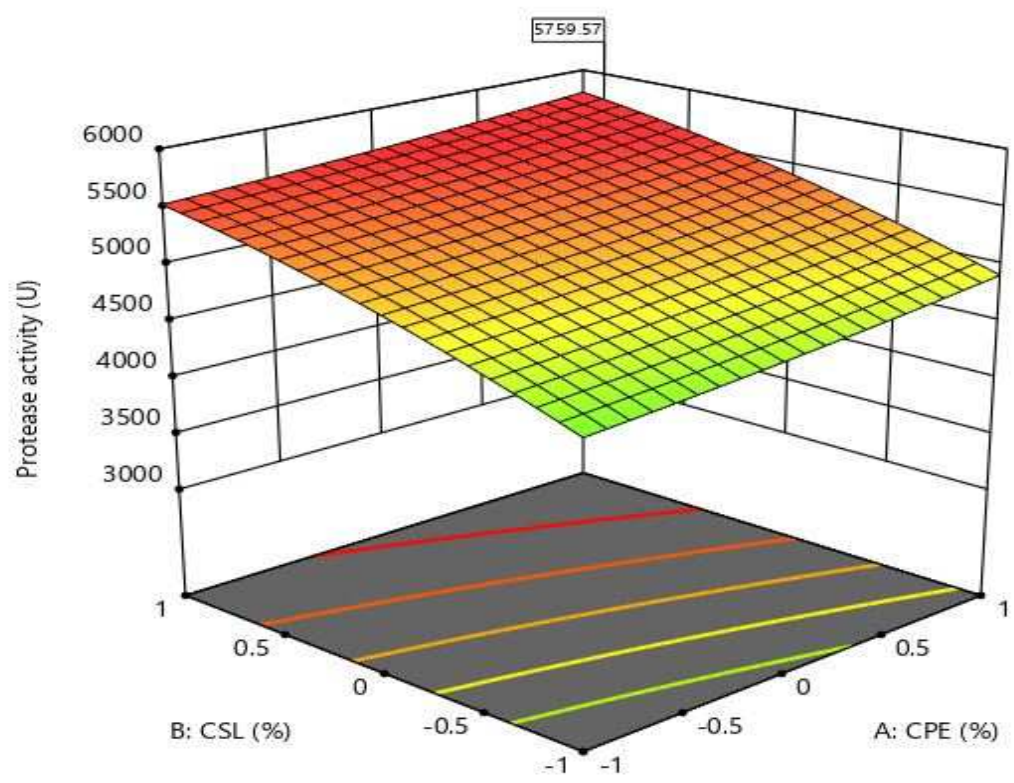

Fig. 5 Optimized contour (A) and surface (B) plots of best two-way variable interaction towards maximum protease activity 


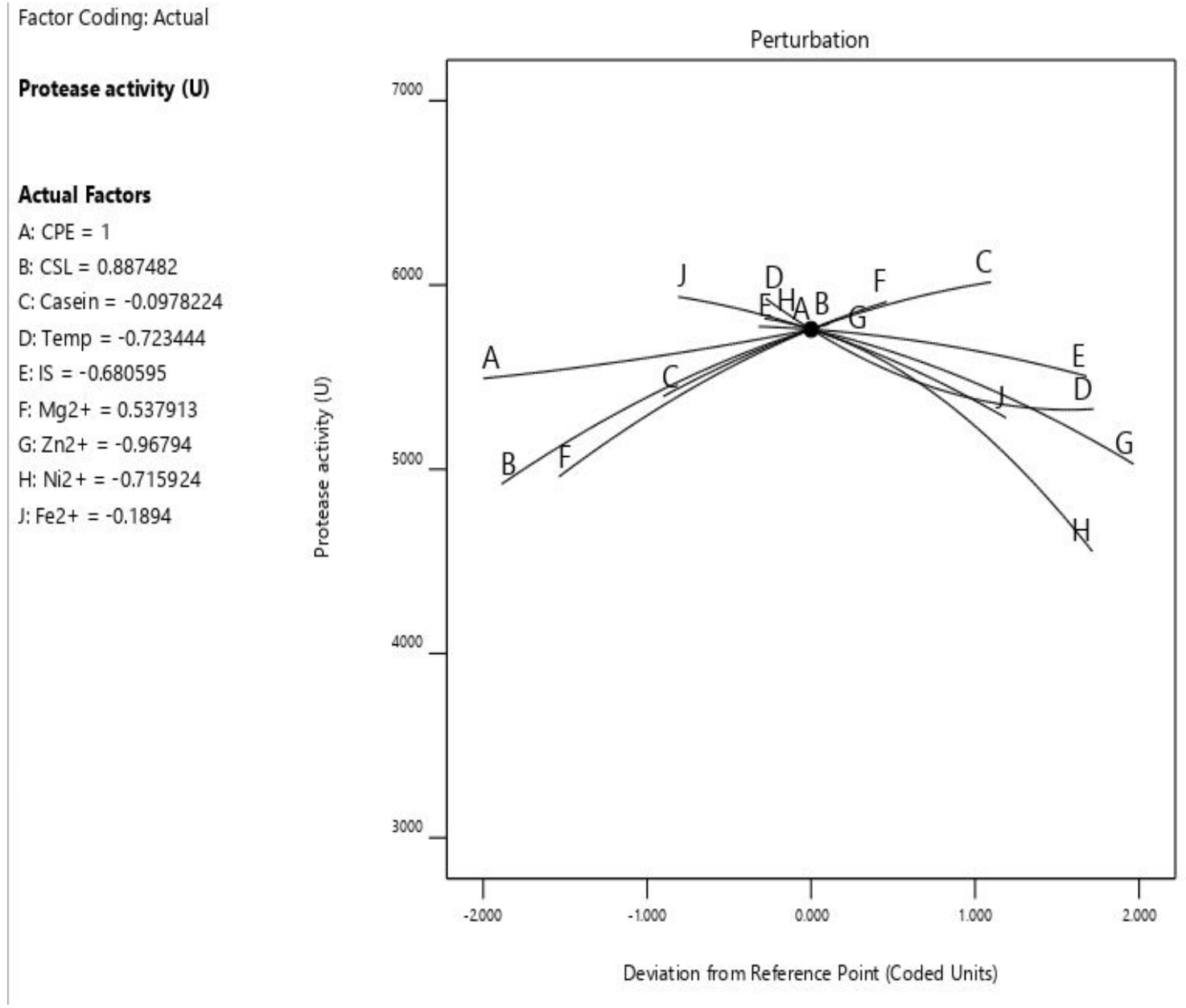

Fig. 6 Perturbation plot of variables at optimized levels towards maximum protease activity 
Figure 8a shows the shake flask (SF) kinetic model fits for product formation, biomass formation and substrate consumption models while $8 \mathrm{~b}$ illustrates the modified Gompertz model fit for bioreactor (BR) scale-up data. Of the two models considered, the logistic model (LM) could only fit biomass formation (BMC) data (not shown) with minimum mean squared error (MSE) and mean absolute error (MAE) while the modified Gompertz model (MGM) was able to fit all three data with the least of errors. The MGM was therefore selected to summarize the kinetic parameters for both SF and BR studies as presented in Tables 3 and 4 . While Table 3 summarizes apparent kinetic model parameters and their performance metric evaluations, Table 4 summarizes all the kinetic parameters, their definitions, units and values from SF and BR experiments, and provides relevant fold increase information. In Table 3, the Logistic model (LM) is reported as giving $\mu_{\max }$ as 0.471 and $0.477 \mathrm{~h}^{-1}$ for SF and BR studies respectively. However, initial, $X_{0}$ and maximum, $X_{\max }$ biomass concentrations were significantly different in SF and BR studies. The LG model performances in SF and BR studies were also in reasonable agreement going by their similar adjusted $r^{2}$ values $(>99.5 \%)$ and mean absolute error $(<3.000)$. The MGM revealed a significantly different $(p<0.05)$ mean lag time for substrate consumption in SF and BR as $3.967 \pm 0.272 \mathrm{~h}$ and $1.422 \pm 0.035 \mathrm{~h}$ respectively. Maximum consumable substrate in the two studies was 71.088 and $267.154 \mathrm{gL}^{-1}$ respectively at maximum consumption rates of $\sim 4$ and $36 \mathrm{gL}^{-1} \mathrm{~h}^{-1}$ respectively. A similar performance metric in terms of adjusted $r^{2}$ (99.99\%), MSE $(<0.8)$ and MAE $(<0.8)$ was reported for the two studies under consideration.

In Table 4, relevant parameters of the modified Gompertz model and derivations are compared for shake flask and bioreactor scale-up studies and reported as fold increase in the last column of the table. Very significantly, this study was designed to demonstrate the biological conversion of cassava processing effluent (CPE) into protease to solve an environmental problem and employ the protease in sundry applications, particularly the detergent industry. Scale-up of the biological conversion led to increase in maximum volumetric rate of substrate consumption by 8.893 -fold. Similarly, maximum volumetric rate of protein production (volumetric productivity) increased by a factor of 9.338 while that of biomass increased approximately 3-fold. However, specific rate of substrate consumption increased 1.87 -fold suggesting a requirement for strain improvement. 


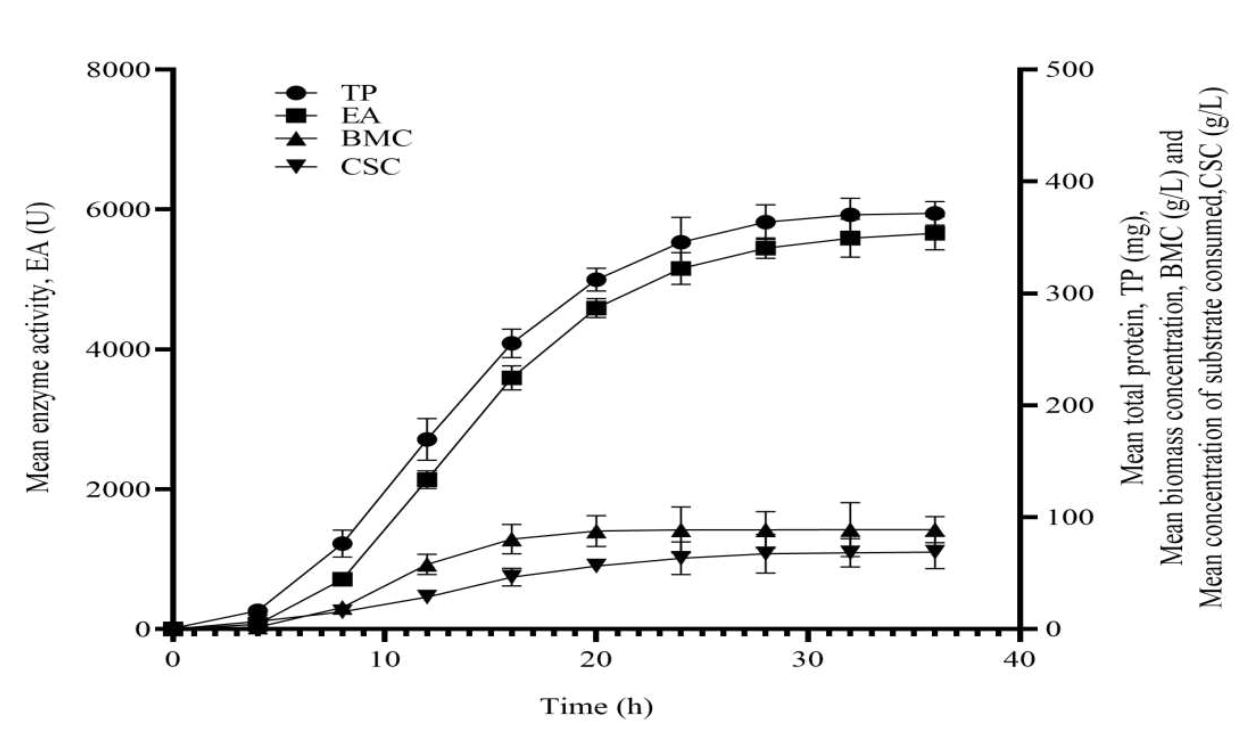

A

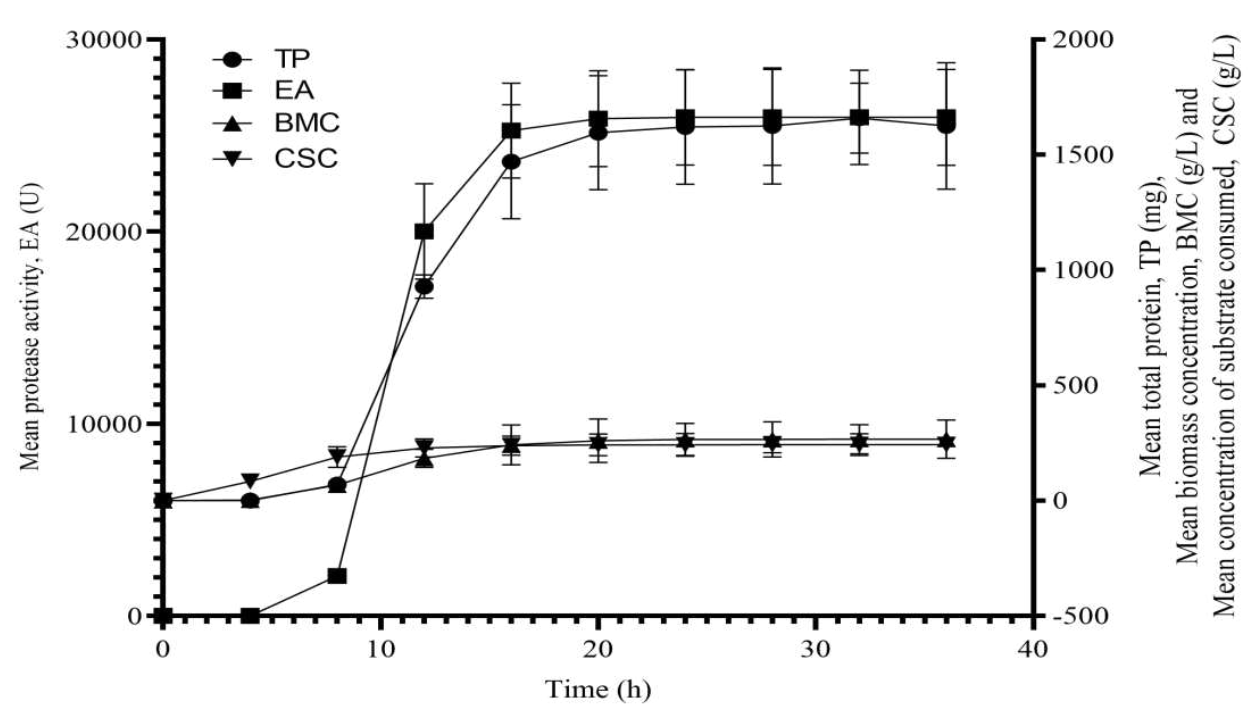

B

Fig. 7 Kinetics of alkaline protease production during cassava processing waste fermentation by Stenotrophomonas acidaminiphila UCCM 00065 in shake flask (A) and bioreactor (B) 


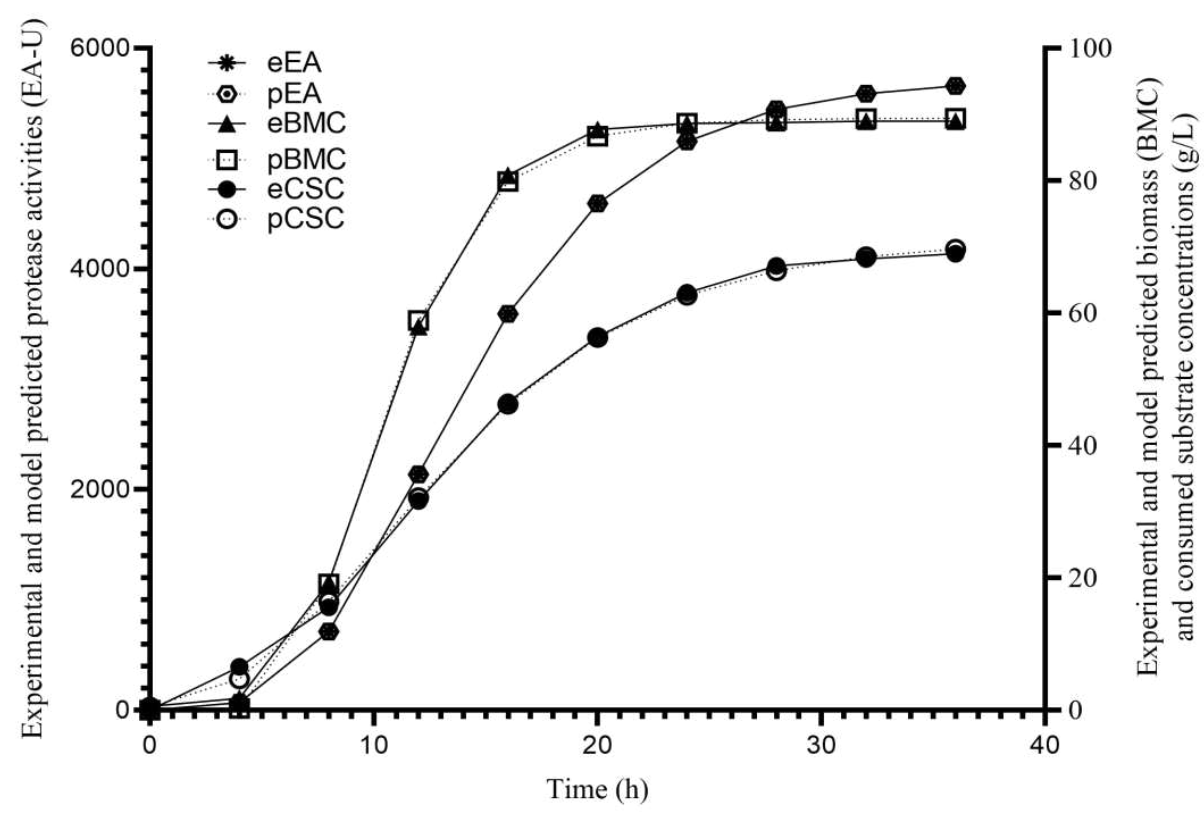

A

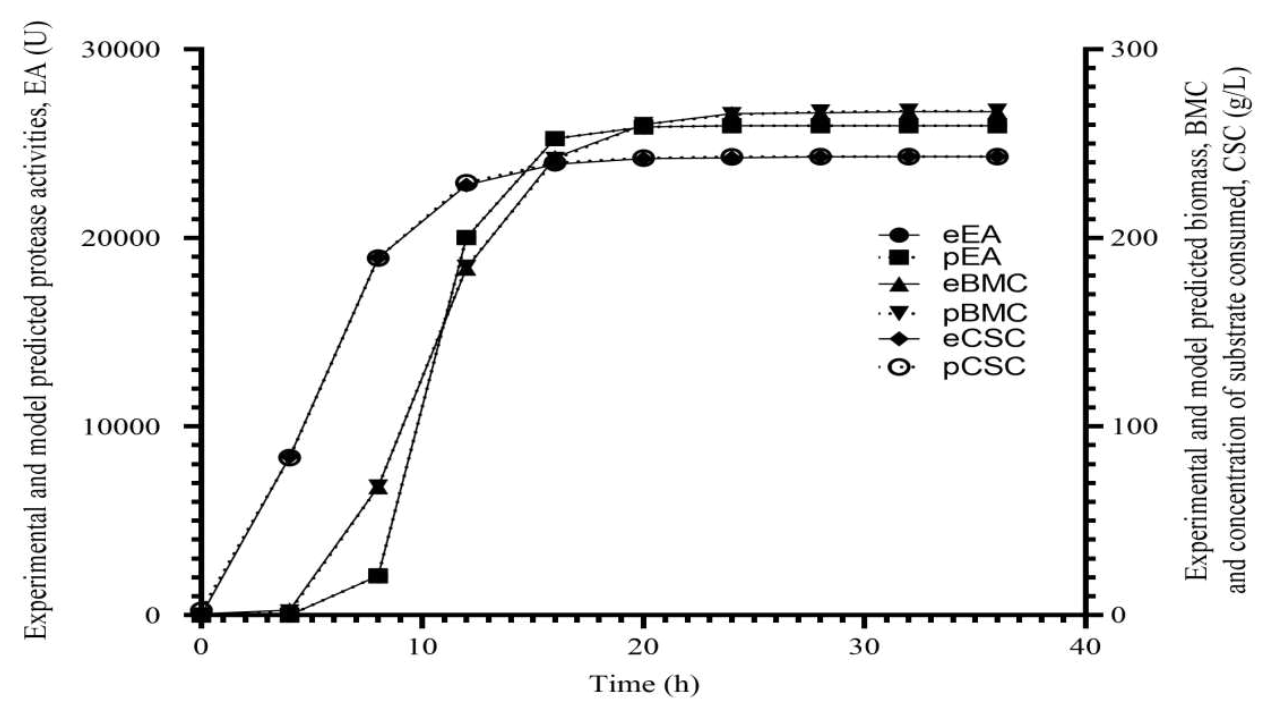

B

Fig. 8 Experimental versus modified Gompertz model predicted response data from shake flask (A) and 5-L bioreactor (B) studies. Dotted lines indicate predicted data while continuous lines indicate experimental data 


\subsection{Aqueous two-phase system purification of alkaline protease}

Results of the purification of the alkaline protease using one step alkaline two-phase system at $\mathrm{pH} 10.5$ is presented as Table 5. The table shows that 1500 molecular weight polyethylene glycol (PEG) purified the protein most with a fold purification of 85.11 and a specific activity of $1291.91 \mathrm{U} / \mathrm{mg}$. Specific activities generally decreased with increase in size of the PEG as PEG-7500 showed lowest specific activity and fold purification of $156.69 \mathrm{U} / \mathrm{mg}$ and 10.32 respectively.

\subsection{Stability of purified protein to surfactants}

The demonstrate the potential suitability of the protease for laundry applications, the purified protease was exposed to three concentrations ( $1 \mathrm{mM}, 5 \mathrm{mM}$ and $10 \mathrm{mM}$ ) of each of sodium dodecyl sulfate (SDS), Triton X-100 and Tween 80. The results of the residual activities of the enzyme are presented as Figure 9 and illustrate that Triton X-100 and Tween 80 denatured the protease at all concentrations resulting in gradual loss of activity relative to the control with increasing surfactant concentration. However, SDS enhanced the activity of the protease with increasing surfactant concentration. Pre-incubation of the enzyme with $10 \mathrm{mM}$ SDS resulted in $92.7 \%$ enhancement of activity relative to the control (100\%). Results of the two-way analysis of variance revealed extremely significant $(p<0.05)$ interaction between surfactant type and concentration. However, surfactant type accounted for $92.2 \%$ of the total variance observed about the data.

\section{Discussion}

Stenotrophomonas acidaminiphila is a pale-yellow, strictly aerobic, Gram-negative rod-shaped bacterium belonging to a narrow genus of only about eight species, with S. maltophila as type species (Assih et al. 2002). Although the bacterium, as well as the type species of its genus, has been described as having great metabolic versatility owing to the wide range of substrates utilized including aromatic hydrocarbons and fipronil (Ryan et al. 2009; Mangwani et al. 2014; Uniyal et al. 2016), only a few carbohydrates or sugars namely maltose, glucose, mannose and fructose are utilized (Assih et al. 2002; Mukherjee and Roy 2016). Although the bacterium does not utilize native starch as whole substrate, its efficient utilization of maltose and glucose prompted its investigation into the bioconversion of the pre-heated starch-based environmental effluent, namely cassava processing effluent (CPE). 
Table 3 Shake flask and bioreactor kinetic model parameters and statistics summary for fermentation responses

\begin{tabular}{|c|c|c|c|c|c|c|c|}
\hline \multicolumn{4}{|c|}{ Biomass formation model parameters } & \multicolumn{4}{|c|}{ Performance metric statistics } \\
\hline LGM & $X_{0}$ & $X_{\max }$ & $\mu_{\max }$ & Adj. $r^{2}$ & MSE & MAE & $p$-value \\
\hline SF & $0.576 \pm 0.061$ & $89.837 \pm 2.153$ & $0.471 \pm 0.007$ & 1.000 & 0.030 & 0.130 & $<0.0001$ \\
\hline $\mathrm{BR}$ & $1.894 \pm 0.089$ & $265.007 \pm 7.324$ & $0.477 \pm 0.031$ & 0.999 & 15.277 & 2.949 & $<0.0001$ \\
\hline MGM & $t_{\text {Lag }}$ & $X_{\max }$ & $r_{\mathrm{xmax}}$ & & & & \\
\hline $\mathrm{SF}$ & $6.270 \pm 0.246$ & $89.417 \pm 1.702$ & $10.749 \pm 0.118$ & 0.999 & 0.540 & 0.656 & $<0.0001$ \\
\hline $\mathrm{BR}$ & $5.896 \pm 0.173$ & $267.308 \pm 3.276$ & $32.086 \pm 1.095$ & 1.000 & 0.263 & 0.459 & $<0.0001$ \\
\hline \multicolumn{8}{|c|}{ Protease activity (product formation) model parameters } \\
\hline MGM & $t_{\text {Lag }}$ & $P_{\max }$ & $r_{\text {pmax }}$ & & & & \\
\hline $\mathrm{SF}$ & $6.577 \pm 0.34$ & $5720.075 \pm 42.289$ & $394.352 \pm 12.006$ & 1.000 & 0.574 & 0.544 & $<0.0001$ \\
\hline $\mathrm{BR}$ & $7.866 \pm 0.02$ & $25950.999 \pm 114.73$ & $5423.721 \pm 23.284$ & 1.000 & 0.041 & 0.217 & $<0.0001$ \\
\hline \multicolumn{8}{|c|}{ Substrate consumption model parameters } \\
\hline MGM & $t_{\mathrm{Lag}}$ & $S_{\max }$ & $r_{\text {smax }}$ & & & & \\
\hline SF & $3.967 \pm 0.272$ & $71.088 \pm 4.357$ & $4.007 \pm 0.014$ & 0.999 & 0.741 & 0.631 & $<0.0001$ \\
\hline $\mathrm{BR}$ & $1.422 \pm 0.035$ & $267.154 \pm 2.354$ & $35.633 \pm 0.621$ & 0.999 & 0.630 & 0.714 & $<0.0001$ \\
\hline
\end{tabular}

LGM = Logistic model; MGM = Modified Gompertz model; SF = Shake flask; $\mathrm{BR}=$ Bioreactor; $P_{\max }=$ maximum protease activity $(\mathrm{U}) ; r_{\mathrm{pmax}}=$ maximum

volumetric rate of protease activity $\left(\mathrm{Uh}^{-1}\right) ; X_{0}=$ initial biomass concentration $\left(\mathrm{gL}^{-1}\right) ; X_{\max }=\operatorname{maximum}$ biomass concentration $\left(\mathrm{gL}^{-1}\right) ; r_{\mathrm{xmax}}=$ maximum volumetric rate of biomass formation $\left(\mathrm{gL}^{-1} \mathrm{~h}^{-1}\right) ; \mu_{\max }=$ maximum specific growth rate $\left(\mathrm{h}^{-1}\right) ; t_{\mathrm{Lag}}=\mathrm{Lag}$ time $(\mathrm{h}) ; S_{\max }=$ Maximum predicted substrate consumption $\left(\mathrm{gL}^{-1}\right) ; r_{\mathrm{smax}}=$ maximum volumetric rate of substrate consumption $\left(\mathrm{gL}^{-1} \mathrm{~h}^{-1}\right)$; Adj. $r^{2}=$ adjusted coefficient of determination; MSE $=$ mean squared error; $\mathrm{MAE}=$ mean absolute error. The kinetic parameter values are means of triplicate determinations \pm standard error. 
Table 4 Kinetic parameter symbols, definitions, units and calculated values from shake flask and bioreactor studies

\begin{tabular}{|c|c|c|c|c|c|}
\hline Parameter & Definition & Unit & $\begin{array}{l}\text { Shake } \\
\text { flask }\end{array}$ & Scale-up & $\begin{array}{c}\text { Fold } \\
\text { increase }\end{array}$ \\
\hline$P_{\mathrm{a}}$ & Product $a$ concentration where $a$ is total protein at time $t$ & $\mathrm{mg}$ & - & - & - \\
\hline$P_{\mathrm{b}}$ & Product $b$ concentration where $b$ is protease activity at time $t$ & $\mathrm{U}$ & - & - & - \\
\hline$P_{\mathrm{a} 0}$ & Protein concentration at onset of exponential protein production & $\mathrm{mg}$ & 48.04 & 73.334 & - \\
\hline$P_{\mathrm{b} 0}$ & Protease activity at onset of exponential protease activity & $\mathrm{U}$ & 585.739 & 2054.039 & - \\
\hline$P_{\mathrm{f}-\mathrm{a}}$ & Final protein concentration & $\mathrm{mg}$ & 371.56 & 1625.978 & - \\
\hline$P_{\mathrm{f}-\mathrm{b}}$ & Final protease activity & $\mathrm{U}$ & 5659.33 & 25950.72 & - \\
\hline$P_{\text {max-a }}$ & Maximum concentration of protein & $\mathrm{mg}$ & 379.193 & 1625.861 & 4.376 \\
\hline$P_{\max -\mathrm{b}}$ & Maximum activity of protease & $\mathrm{U}$ & 5720.075 & 25950.999 & 4.586 \\
\hline$t_{L \mathrm{p}-\mathrm{a}}$ & Lag time at onset of exponential protein production & $\mathrm{h}$ & 5.019 & 8.331 & - \\
\hline$t_{L \mathrm{p}-\mathrm{b}}$ & Lag time at onset of exponential activity of protease & $\mathrm{h}$ & 6.577 & 7.866 & - \\
\hline$r_{\text {pmax-a }}$ & Maximum volumetric rate of protein production (volumetric productivity) & $\mathrm{mgL}^{-1} \mathrm{~h}^{-1}$ & 27.553 & 257.303 & 9.338 \\
\hline$r_{\text {pmax-b }}$ & Maximum volumetric rate of protease activity & $\mathrm{Uh}^{-1}$ & 394.352 & 5423.721 & 13.753 \\
\hline$X_{0}$ & Biomass concentration at onset of exponential biomass formation & $\mathrm{gL}^{-1}$ & 15.21 & 3.921 & - \\
\hline$X_{\mathrm{f}}$ & Final biomass concentration & $\mathrm{gL}^{-1}$ & 88.99 & 266.34 & - \\
\hline$X_{\max }$ & Maximum biomass concentration & $\mathrm{gL}^{-1}$ & 89.417 & 267.308 & - \\
\hline$\mu_{\max }$ & Maximum specific growth rate & $\mathrm{h}^{-1}$ & 0.417 & 0.477 & - \\
\hline$r_{\mathrm{xmax}}$ & Maximum volumetric rate of biomass formation & $\mathrm{gL}^{-1} \mathrm{~h}^{-1}$ & 10.749 & 32.086 & 2.985 \\
\hline$t_{L x}$ & Lag time at onset of exponential biomass formation & $\mathrm{h}$ & 6.269 & 5.896 & - \\
\hline$S_{0}$ & Concentration of substrate consumed at onset of exponential substrate consumption & $\mathrm{g} / \mathrm{L}$ & 6.784 & 29.878 & - \\
\hline$S_{\mathrm{f}}$ & Final amount of substrate consumed & $\mathrm{g} / \mathrm{L}$ & 68.88 & 243.22 & 3.53 \\
\hline$S_{\max }$ & Maximum amount of substrate consumed & $\mathrm{g} / \mathrm{L}$ & 71.088 & 267.148 & 3.758 \\
\hline$r_{\text {smax }}$ & Maximum volumetric rate of substrate consumption & $\mathrm{gL}^{-1} \mathrm{~h}^{-1}$ & 4.007 & 35.632 & 8.893 \\
\hline$t_{L \mathrm{sc}}$ & Lag time at onset of exponential substrate consumption & $\mathrm{h}$ & 3.967 & 1.422 & - \\
\hline$Y_{p / x-a}$ & Specific yield of protein & $\mathrm{mgg}^{-1}$ & 4.385 & 5.917 & 1.349 \\
\hline$Y_{p / x-b}$ & Specific protease activity yield & $\mathrm{U}^{-1} \mathrm{gL}^{-1}$ & 68.767 & 91.063 & 1.324 \\
\hline$Y_{x / s}$ & Specific biomass yield relative to amount of substrate consumed & $\mathrm{gg}^{-1}$ & 1.19 & 1.23 & - \\
\hline$Y_{\mathrm{p} / \mathrm{s}-\mathrm{a}}$ & Protein yield relative to amount of substrate consumed & $\mathrm{mgg}^{-1}$ & 5.21 & 7.28 & - \\
\hline $\mathrm{Y}_{\mathrm{p} / \mathrm{s}-\mathrm{b}}$ & Protease activity relative to amount of substrate consumed & $\mathrm{Ug}^{-1}$ & 81.71 & 112.01 & - \\
\hline $\mathrm{q}_{\mathrm{p}-\mathrm{a}}$ & Specific rate of protein production (specific productivity) & $\mathrm{mg}^{-1} \mathrm{gDCWh}^{-1}$ & 48.87 & 110.48 & 2.26 \\
\hline $\mathrm{q}_{\mathrm{s}}$ & Specific rate of substrate consumption & $\mathrm{g}^{-1} \mathrm{gDCWh}^{-1}$ & 8.83 & 16.51 & 1.87 \\
\hline
\end{tabular}


Table 5

Effect of molecular weight (Mol.wt) of polyethylene glycol (PEG) on specific activity, yield and fold of protease from aqueous two-phase system (ATPS) purification

\begin{tabular}{|c|c|c|c|c|c|c|}
\hline Purification step & $\begin{array}{c}\text { PEG } \\
\text { Mol.wt }\end{array}$ & $\begin{array}{c}\text { Total protein } \\
(\mathrm{mg})\end{array}$ & $\begin{array}{c}\text { Total activity } \\
(\mathrm{U})\end{array}$ & $\begin{array}{c}\text { Specific activity } \\
(\mathrm{U} / \mathrm{mg})\end{array}$ & Yield (\%) & Fold purification \\
\hline Shake flask crude extract & & 378.65 & 5748.46 & 15.18 & 100.00 & 1.00 \\
\hline ATPS with & 1500 & 0.35 & 452.17 & 1291.91 & 7.87 & 85.11 \\
\hline & $\begin{array}{l}3000 \\
4500 \\
6000 \\
7500 \\
\end{array}$ & $\begin{array}{c}1.57 \\
4.41 \\
7.42 \\
16.48 \\
\end{array}$ & $\begin{array}{l}1386.36 \\
1884.23 \\
2157.74 \\
2582.18 \\
\end{array}$ & $\begin{array}{l}883.03 \\
427.26 \\
290.80 \\
156.69 \\
\end{array}$ & $\begin{array}{l}24.12 \\
32.78 \\
37.54 \\
44.92 \\
\end{array}$ & $\begin{array}{l}58.17 \\
28.15 \\
19.16 \\
10.32 \\
\end{array}$ \\
\hline $\begin{array}{l}\text { 5-L Bioreactor } \\
\text { crude extract } \\
\text { ATPS with } \\
\text { PEG/Na } / \mathrm{Na}^{+} \text {Citrate }\end{array}$ & 1500 & $\begin{array}{c}1625.29 \\
0.26\end{array}$ & $\begin{array}{c}25950.72 \\
358.35\end{array}$ & $\begin{array}{c}15.97 \\
1378.27\end{array}$ & $\begin{array}{c}100.00 \\
1.38\end{array}$ & $\begin{array}{c}1.00 \\
86.30\end{array}$ \\
\hline
\end{tabular}




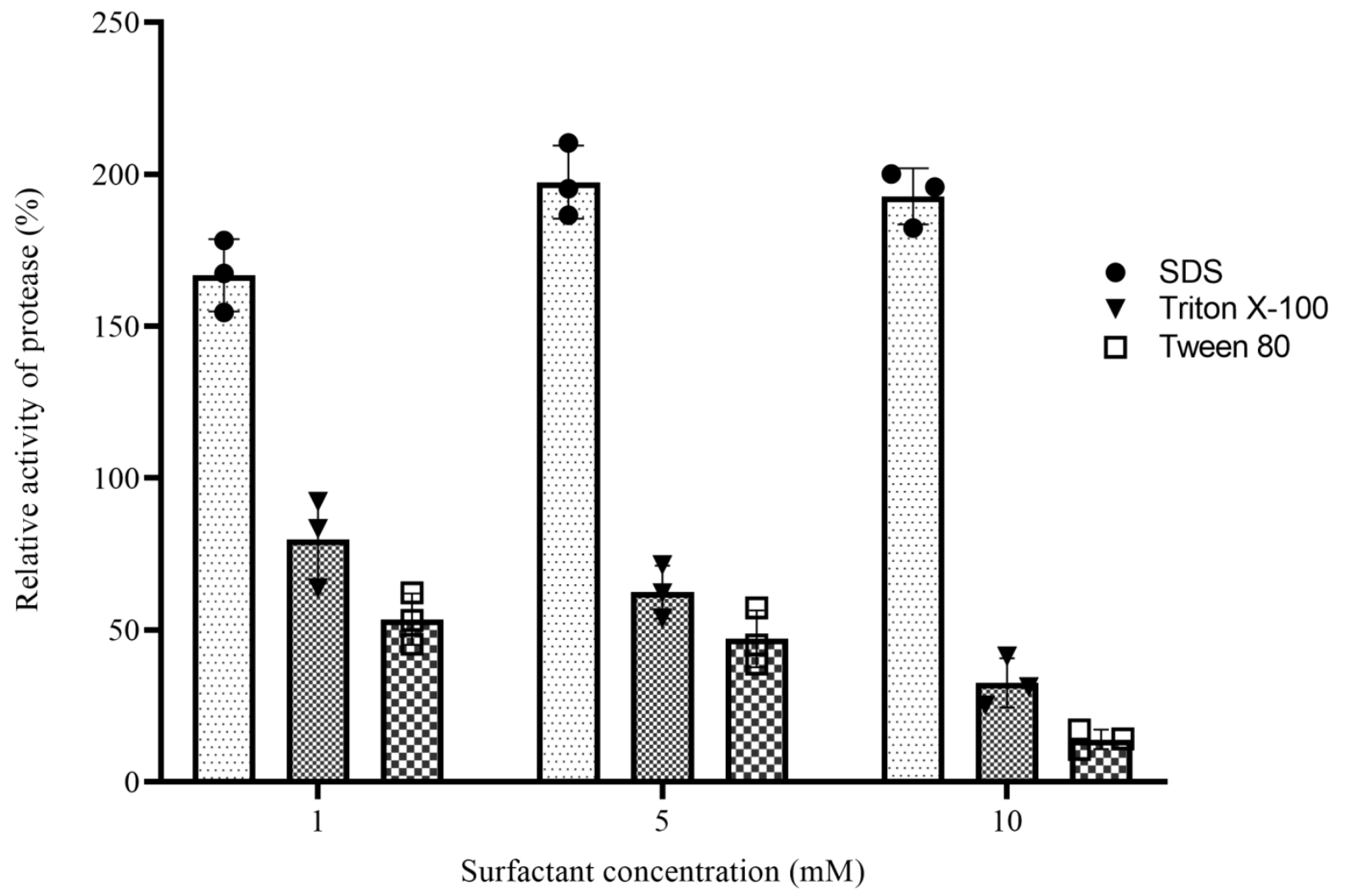

Fig. 9 Relative activity versus surfactant concentration plot to determine stability of alkaline protease and potential for application in detergent industry 
For many years, cassava processing has been a major activity in Nigeria but disposal of waste arising therefrom has remained a major challenge and an environmental concern.

Considering the possibility of interaction between and among significant variables selected through onefactor-at-a-time (OFAT) approach (Edet et al. 2018), the regular 2-level factorial design (2-LFD) was adopted in preference to the popular Placket-Burman design (PBD) to screen for significant bioconversion process variables. The percent contributions of such interaction terms as $\mathrm{CPE}^{*} \mathrm{pH}, \mathrm{CPE}$ agitation, $\mathrm{CPE}^{*} \mathrm{Ca}^{2+}, \mathrm{CPE}^{*} \mathrm{Ni}^{2+}$ and $\mathrm{CPE} * \mathrm{Zn}^{2+}$ lend credence to the choice of the screening methodology. Very significantly, the linear effect of agitation was not significant in the study, nevertheless, the interaction term of CPE*agitation was significant suggesting that effect of agitation speed on fermentation could be a function of nature and/or amount of carbon source or that nature of medium determines the speed of agitation required to distribute oxygen in the system.

Selection of corn steep liquor as nitrogen source for synthesis of protease was not surprising because the complex medium contains almost all the amino acids in casamino acids which the bacterium utilizes readily as nitrogen source (Edet et al. 2018). Apart from amino acids, corn steep liquor also supplies the readily metabolizable invert sugars to enhance growth. The significance of divalent cations like $\mathrm{Mg}^{2+}, \mathrm{Zn}^{2+}, \mathrm{Ni}^{2+}$ and $\mathrm{Fe}^{2+}$ may indicate the extra requirement of these nutrients to compensate for their low levels in the ash content of corn steep liquor and suggest the enzyme as a metallo-protease ( $\mathrm{Li}$ et al. 2016). Concentrations of the divalent cations also regulate the ionic strength of the medium which also significantly influenced the bioconversion process and enhanced protease activity. This complex medium has been reported as a reliable nitrogen source for microbial fermentations since the discovery of penicillin (Sherpa et al. 2021). Temperature is an important factor in the growth and metabolism of Stenotrophomonas acidaminiaphila as well as other related species. The study bacterium has a fairly wide mesophilic temperature of growth; 28-5-42.5 ${ }^{\circ} \mathrm{C}$ (Ghosh and Saha 2013; Edet et al. 2018; Sherpa et al. 2021), nevertheless, some sort of synergy between growth and protease biosynthesis had to be achieved.

The path of steepest ascent was most successful in guiding the variable conditions towards optimum levels. When the enzyme activity at the steepest ascent was compared with that obtained from RSM model and optimization, very little difference was found suggesting a remarkably successful path of steepest ascent experimentation. Frequently in literature, RSM is reported without regard to the path of steepest ascent experiment. This generates misleading optimum bioprocess conditions that may result in either underestimated and/or 
overestimated yield of target metabolite, with the consequent difficulty in scale-up and/or pilot studies. Response surface methodology is a sequential statistical procedure that typically involves four stages which must be followed painstakingly. It is impossible therefore to move from a factor selection process straight into RSM, the results of which would only come by guess-setting the levels. The method of steepest ascent has been successfully exploited by various researchers towards locating optimum conditions of significant bioprocess variables (Yingling and Zhengfang 2013; Long et al. 2018). In recent times, artificial neural network (ANN) has emerged as an alternative method to RSM for predicting optimum levels of bioprocess factors and has frequently been demonstrated as being superior. However, if the fitted model performance metric; adjusted $r^{2}$ from an RSM experiment; is able to explain up to $98 \%$ of the variations about the data, then the alternative ANN would be of little or no relevance (Karri and Sahu 2018; Lau et al. 2020). In this report, the second-order model equation for protease activity yielded an adjusted $r^{2}$ of $99.99 \%$ and could therefore satisfactorily serve as fitness function for the optimization experiment. The optimum conditions of the significant variables were shown to lead to high protease activity by the study bacterium which was confirmed in triplicate shake flask experiments. Successful application of RSM for modeling and optimization of process parameters for metabolite production and environmental remediation has been copiously documented (Olubunmi et al. 2020; Karray et al. 2021).

Production kinetic studies typically attempt to uncover some key parameters of presumed optimized experiments. In a study where waste bioconversion and enzyme activity were the desired goals, maximum volumetric rate of substrate consumption and specific product formation are viewed as key kinetic parameters to be maximized. A comparison of shake flask kinetics and that in 5-L bioreactor as scale-up attempt for the bioprocess, revealed satisfactory results. Total amount of reducing sugar consumed by the bacterium significantly increased 3.76-fold in the bioreactor at a maximum volumetric rate which increased by a factor of 8.89 . This suggests that great potential exists for scale-up of the bioprocess. Total activity of Stenotrophomonas acidaminiphila UCCM 00065 alkaline protease was $25,950.72 \mathrm{U}$ in the bioreactor study while 5,748.46 $\mathrm{U}$ was observed in shake flask experiments from crude total protein of $1625.29 \mathrm{mg}$ and $378.65 \mathrm{mg}$ respectively. Such high alkaline protease activity and total protein have earlier been reported in a few bacteria like Bacillus stereothermophilus (Karray et al. 2021) and Bacillus pumilus strain MK6-5 (Ozcelik et al. 2014) after employing different methods of optimization. Successful exploitation of bacteria in waste treatment with simultaneous production of value-added metabolite has been recommended for reduction in microbial bioprocess economics (Ekpenyong et al. 2021c). Kumar et al. (2015) 
reported the simultaneous production of lipid during dairy wastewater treatment by Rhodococcus opacus in a batch bioreactor with applications in biodiesel production and Olubunmi et al. (2020) produced biodiesel during restaurant waste oil treatment. Our results suggest that the study bacterium could be exploited for concomitant alkaline protease production and treatment of cassava processing waste.

Attempts at modeling the kinetics of protease production and substrate consumption using the modified Gompertz and logistic models (Mercier et al. 1992) revealed that the logistic model (LM) could not fit protease activity and substrate consumption data adequately. However, the model could fit $99.9 \%$ of bacterial growth data, albeit with mean squared error (MSE) of 15.28. The model also gave a maximum specific growth rate, $\mu_{\max }$, of the bacterium under shake flask and bioreactor conditions as 0.47 and $0.48 \mathrm{~h}^{-1}$ respectively, corresponding to generation times of 1.47 and $1.44 \mathrm{~h}$ respectively. These generation times differ markedly from the $0.64 \mathrm{~h}$ of the bacterium in glucose-basal medium (data not shown). The MGM, on the other hand, could fit all three response data more adequately with minimal MSE of 0.26. Kinetics of bioconversion experiments such as this have earlier been successfully modeled by the MGM (Tjørve and Tjørve 2017; Sulieman et al. 2018; Boshagh and Rostami 2021) and is also recommended in this report.

The study enzyme was purified by the aqueous two-phase system using polyethylene glycol with molecular weight of 1500 in association with sodium citrate. When results of specific enzyme activity, yield and fold purification were compared to those obtained from a combination of precipitation and column chromatography (data not shown), the later results were set aside and the former upheld for this study. This biphasic system purification had earlier been applied to the extraction of alkaline proteases from cell-free Bacillus subtilis TISTR 25 fermentation broth (Chouyyok et al. 2005) and Bacillus amyloliquefaciens B7 (Abd Samad et al. 2017). With the 87fold purification of the protein, more reliable results of characterization and kinetic studies on the protein could be obtained.

To demonstrate potential for application of the alkaline protease in the detergent industry, results of preexposure of the purified enzyme to different detergents revealed stability of the enzyme to sodium dodecyl sulfate (SDS) with increased activity occurring with increased concentration of SDS. These results are in concord with a number of findings for other bacteria (Ozcelik et al. 2014), the only difference being in the extent of stability which Stenotrophomonas acidaminiphila strain UCCM 00065 possesses great advantage. This suggests that the protease 
extracted from cassava processing waste bioconversion could be further employed in a gainful venture like formulation of detergents for household and industrial dishwashing purposes.

Conclusions

Stenotrophomonas acidaminiphila UCCM 00065 produced alkaline protease during bioconversion of pregelatinized cassava processing effluent. A regular two-level factorial designed (2-LFD) experiment selected additional eight factors which linear and interaction terms significantly influenced substrate consumption and subsequent protease activity. A central composite rotatable designed experiment of a surface methodology using factor levels that produced maximum enzyme activity in the path of steepest ascent improved total enzyme activity by 35.82 -fold in shake flasks and 163.41-fold under bioreactor conditions. Cassava waste bioconversion in the bioreactor therefore improved significantly by a factor of 8.89 after shake flask optimization with reduced fermentation time. We conclude that statistical optimizations are useful to improve microbial productions through identification and setting of levels of significant factors for efficient bioconversion of substrates and that production in bioreactors are dependable indices for scale-up of the bioprocess.

\section{References}

Abd Samad NS, Amid A, Jimat DN, Ab.Shukor NA (2017) Protease purification from Bacillus amyloliquefaciens B7 using aqueous two-phase system (ATPS). Int. Food Res. J. 24:S292-S297.

https://doi.org/10.26480/gws.01.2017.07.09

Abusham RA, Zaliha RN, Rahman RA, Salleh AB, Basri M (2009) Optimization of physical factors affecting the production of thermo-stable organic solvent-tolerant protease from a newly isolated halotolerant Bacillus subtilis strain Rand. Microb Cell Fact 8:20. https://doi.org/10.1186/1475-2859-8-20

Ammasi R, Victor JS, Chellan R, Chellappa M (2020) Alkline protease for an efficacious rehydration of skin matrix by a novel Bacillus crolab MTCC 5468 in sustainable leather production: a green approach. Biotechnol Lett 42:249267. https://doi.org/10.1007/s10529-019-02769-0

Asitok AD, Antai SP, Ekpenyong MG (2017) Water soluble fraction of crude oil uncouples protease biosynthesis and activity in hydrocarbonoclastic bacteria; implications for natural attenuation. Int J Sci 6:5-21. https://dx.doi.org/10.18483/ijSci.1344

Assih EA, Ouattara AS, Thierry S, Cayol J-L, Labat M, Macarie H (2002) Stenotrophomonas acidaminiphila sp. nov., a strictly aerobic bacterium isolated from an upflow anaerobic sludge blanket (UASB) reactor. Int J Syst Evol Microbiol 52:559-568. https://doi.org/10.1099/00207713-52-2-559

Boshagh F, Rostami K (2021) Kinetic models of biological hydrogen production by Enterobacter aerogenes. Biotechnol Lett 43:435-443. https://doi.org/10.1007/s10529-020-03051-4 
Dwibedi V, Rath SK, Prakash R, Saxena S (2021) Response surface statistical optimization of fermentation parameters for resveratrol production by the endophytic fungus Arcopilus aureus and its tyrosinase inhibitory activity. Biotechnol Lett 43:627-644. https://goi.org/10.1007/s10529-020-03032-7

Edet PE, Asitok AD, Ekpenyong MG, Antai SP (2018) Evaluation of the effects of nutritional and environmental parameters on production of extracellular caseinolytic protease by Stenotrophomonas acidaminiphila strain BPE4. Int J Sci 7:70-81. https://doi.org/10.18483/ijSci.1548

Ekpenyong MG, Antai SP, Asitok AD, Ekpo BO (2017a) Response surface modeling and optimization of major medium variables for glycolipopeptide production. Biocatal Agric Biotechnol 10:113-121. https://doi.org/10.1016/j.bcab.2017.02.015

Ekpenyong MG, Antai SP, Asitok AD, Ekpo BO (2017b) Plackett-Burman design and response surface optimization of medium trace nutrients for glycolipopeptide biosurfactant production. Iranian Biomed J 21:249-260. https://dx.doi/10.18869/acadpub.ibj.21.4.249

Ekpenyong MG, Asitok AD, Antai SP, Antigha RE, Ogarekpe NM, Antai AS, Ogbuagu UR, Ayara NN (2021c) Kinetic modeling and quasi-economic analysis of fermentative glycolipopeptide biosurfactant production in a medium co-optimized by statistical and neural network approaches. Prep Biochem Biotechnol 51:450-466. https://doi.org/10.1080/10826068.2020.1830414

Ekpenyong MG, Asitok AD, Antai SP, Ekpo BO, Antigha RE, Ogarekpe NM (2021a) Statistical and artificial neural network approaches to modeling and optimization of fermentation conditions for production of a surface/bioactive glyco-lipo-peptide. Int J Pept Res Ther 27:475-495. https://doi.org/10.1007/s10989-020-10094-8

Ekpenyong MG, Asitok AD, Antigha RE, Ogarekpe NM, Ekong US, Asuquo MI, Essien JP, Antai SP (2021b) Bioprocess optimization of nutritional parameters for enhanced anti-leukemic L-asparaginase production by Aspergillus candidus UCCM 00117: a sequential statistical approach. Int J Pept Res Ther 27:1501-1527. https://doi.org/10.1007/s10989-021-10188-x

Ghosh A, P.D. Saha PD (2013) Optimization of copper bioremediation by Stenotrophomonas maltophila PD2. J Environ Chem Eng 1:159-163. https://doi.org/10.1016/j.jece.2013.04.012

Gupta R, Beg Q, Lorenz P (2002) Bacterial alkaline proteases: molecular approaches and industrial applications, Appl Microbiol Biotechnol 59:15-32. https://doi.org/10.1007/s00253-002-0975-y

Kanno AI, Leite LCC, Pereira LR, Rodrigues de Jesus MJ, Andreata-Santos R, Alves RPDS, Durigon EL, Ferreira LCS, Gonçalves VM (2020) Optimization and scale-up production of Zika virus $\triangle$ NS1 in Escherichia coli: application of response surface methodology. AMB Expr 10: 1. https://doi.org/10.1186/s13568-019-0926-y

Karray A, Alonazi M, Horchani H, Bacha AB (2021) A novel thermostable and alkaline protease produced from Bacillus stearothermophilus isolated from Olive Oil Mill Sols suitable to industrial biotechnology. Molecules 26:1139. https://doi.org/10.3390/molecules26041139

Karri RR, Sahu JN (2018) Modeling and optimization by particle swarm embedded neural network for adsorption of zinc (II) by palm kernel shell based activated carbon from aqueous environment. J Environ Manage 206:178-191. https://doi.org/10.1016/j.jenvman.2017.10.026

Kumar S, Gupta N, Pakshirajan K (2015) Simultaneous lipid production and dairy wastewater treatment using Rhodococcus opacus in a batch bioreactor for potential biodiesel application. J Environ Chem Eng 3:1630-1636. https://doi.org/10.1016/j.jece.2015.05.030 
Lau YJ, Karri RR, Mubarak NM, Lau SY, Chua HB, Khalid M, Jagadish P, Abdullah E.C (2020) Removal of dye using peroxidase-immobilized Buckypaper/polyvinyl alcohol membrane in a multi-stage filtration column via RSM and ANFIS. Environ Sci Poll Res 27:40121-40134. https://doi.org/10.1007/s11356-020-10045-2

Lazim H, Mankai H, Slama N, Barkallah I, Limam F (2009) Production and optimization of thermophilic alkaline protease in solid-state fermentation by Streptomyces sp. CN902. J Ind Microbiol Biotechnol 36:531-537. https://doi.org/10.1007/s10295-008-0523-6

Li X, Xu W, Yang J, Zhao H, Xin H, Zhang Y (2016) Effect of different levels of corn steep liquor addition on fermentation characteristics and aerobic stability of fresh rice straw silage. Animal Nutr 2:345-350. https://doi.org/10.1016/j.aninu.2016.04.007

Long J, Zhao X, Liang F, Liu N, Sun Y, Xi Y (2018) Optimization of fermentation conditions for an Escherichia coli strain engineered using the response surface method to produce a novel therapeutic DNA vaccine for rheumatoid arthritis. J Biol Eng 12:22-31. https://doi.org/10.1186/s13036-018-0110-y

Mangwani N, Shukla SK, Kumari S, Rao TS, Das S (2014) Characterization of Stenotrophomonas acidaminiphila NCW-702 biofilm for implication in the degradation of polycyclic aromatic hydrocarbons. J Appl Microbiol 117:1012-1024. https://doi.org/10.1111/jam.12602

Mercier P, Yerushalmi L, Rouleau D, Dochain D (1992) Kinetics of lactic acid fermentation on glucose and corn by Lactobacillus amylophilus. J Chem Technol Biotechnol 55:111-121. https://doi.org/10.1002/jctb.280550204

Miller GL (1959) Use of dinitrosalicylic acid reagent for determination of reducing sugar. Anal Chem. 31:426-428. https://doi.org/10.1021/ac60147a607

Mukherjee P, Roy P (2016) Genomic potential of Stenotrophomonas maltophilia in bioremediation with an assessment of its multifaceted role in our environment. Front Microbiol 7:967.

https://doi.org/10.3389/fmicb.2016.00967

Olubunmi BE, Karmakar B, Aderemi OM Akpan UG, Auta M, Halder G (2020) Parametric optimization by Taguchi L9 approach towards biodiesel production from restaurant waste oil using Fe-supported anthill catalyst. J Environ Chem Eng 8: https://doi.org/10.1016/j.jece.2020.104288

Ozcelik B, Aytar P, Gedikli S, Yardimci E, Caliskan F, Cabuk A (2014) Production of an alkaline protease using Bacillus pumilus D3 without inactivation by SDS, its characterization and purification. J Enzyme Inhib Med Chem 29:388-396. https://doi.org/10.3109/14756366.2013.788503

Razzaq A, Shamsi S, Ali A, Ali Q, Sajjad M, Malik A, Ashraf M (2019) Microbial proteases applications. Front Bioeng Biotechnol 7:110. https://doi.org/10.3389/fbioe.2019.00110

Rodrigues L, Moldes A, Teixeira J, Oliveira R (2006) Kinetic study of fermentative biosurfactant production by Lactobacillus strains. Biochem Eng J 28:109-116. https://doi.org/10.1016/j.bej.2005.06.001

Ryan RP, Monchy S, Cardinale M, Taghavi S (2009) The versatility and adaptation of bacteria from the genus Stenotrophomonas. Nat Rev Microbiol 7:514-525. https://doi.org/10.1038/nrmicro2163

Saggu SK, Mishra PC (2017) Characterization of thermostable alkaline proteases from Bacillus infantis SKS1 isolated from garden soil. PloS ONE 12:e0188724. https://doi.org/10.1371/journal.pone.0188724 
Salahi A, Noshadi I, Badrnezhad R, Kanjilal B, Mohammadi T (2013) Nano-porous membrane process for oily wastewater treatment: Optimization using response surface methodology. J Environ Chem Eng 1:218-225. https://doi.org/10.1016/j.jece.2013.04.021

Saxena R, Singh R (2010) Statistical optimization of conditions for protease production from Bacillus sp. Acta Biol. Szegediensis 54:135-141

Sherpa MT, Das S, Najar IN, Thakur N (2021) Draft genome sequence of Stenotrophomonas maltophilia strain P13 gives insight into its protease production and assessment of sulfur and nitrogen metabolism. Curr Res Microb Sci 2:100012. https://doi.org/10.1016/j.crmicr.2020.100012

Sulieman AK, Putra MD, Abasaeed AE, Gaily MH, Al-Zahrani SM, Zeinelabdeen MA (2018) Kinetic modeling of the simultaneous production of ethanol and fructose by Saccharomyces cerevisiae. Electron J Biotechnol 34:1-8. https://doi.org/10.1016/j.ejbt.2018.04.006

Tjørve KMC, Tjørve E (2017) The use of Gompertz models in growth analyses, and new Gompertz-model approach: an addition to the Unified-Richards family. PloS ONE 12:e0178691.

https://doi.org/10.1371/journal.pone.0178691

Truppo MD (2017) Biocatalysis in the pharmaceutical industries: the need for speed. ACS Med. Chem. Lett. 8:476480. https://doi.org/10.1021/acsmedchemlett.7b00114

Uniyal S, Paliwal R, Sharma RK, Rai JPN (2016) Degradation of fipronil by Stenotrophomonas acidaminiphila isolated from rhizospheric soil of Zea mays. 3 Biotech 6:48. https://doi.org/10.1007/s13205-015-0354-x

Yingling B, Zhengfang Y (2013) Application of an integrated statistical design for optimization of culture condition for ammonium removal by Nitrosomonas europaea, PloS ONE 8:e60322.

https://doi.org/10.1371/journal.pone.0060322

Chouyyok W, Wongmongkol N, Siwarungson N, Prichanont S (2005) Extraction of alkaline protease using an aqueous two-phase system from cell free Bacillus subtilis TISTR 25 fermentation broth. Proc Biochem 40:35143518. https://doi.org/10.1016/j.procbio.2005.03.052 